\title{
NOVEL VERSATILE SYNTHESIS OF SUBSTITUTED TETRABENZOPORPHYRINS
}

\section{SUPPORTING INFORMATION}

Olga S. Finikova, ${ }^{a}$ Andrei V. Cheprakov, ${ }^{a} *$ Irina P. Beletskaya, ${ }^{a}$ Patrick J. Carroll, ${ }^{b}$ and Sergei A. Vinogradov ${ }^{c *}$

${ }^{a}$ Department of Chemistry, Moscow State University, 119899 Moscow, Russia

${ }^{b}$ Crystallographic Laboratory, Department of Chemistry, University of Pennsylvania, Philadelphia, PA 19104

${ }^{c}$ Department of Biochemistry and Biophysics, University of Pennsylvania, Philadelphia, PA 19104

UV-VIS data of porphyrins and metalloporphyrins S3

$\mathrm{X}$-ray Structure Determination___ S4

Normal-Coordinate Structural Decomposition (NSD) Analysis___ S6

Computational Data S6

References and Notes S7

NMR spectra S8

I. Pyrroles S9

II. $\mathrm{Ar}_{4} \mathrm{TCHP}$ S15

III. $\mathrm{Ar}_{4} \mathrm{TBP}$ S16 


\section{Experimental Section}

All solvents were purified according to the standard procedures. Selecto silica gel (Fisher Scientific, Inc.) was used for column chromatography. All the starting materials (sulfolene 1a, dimethyl maleate, aldehydes, etc) were obtained from commercial sources. Static fluorescence and phosphorescence measurements were performed on a spectrofluorometer equipped with an infra-red enhanced R2658P PMT. Phosphorescence lifetimes were measured using an in-house constructed frequency domain phosphorometer. ${ }^{1}$ Solutions for phosphorescence measurements were deoxygenated by bubbling of Ar, after which the cuvettes were sealed. The absorbances of the samples at the wavelengths used for excitation were kept below 0.15 OD. The quantum yields were obtained by computing the integrals of the corrected emission spectra and referencing them to the fluorescence quantum yield of ZnTPP in deoxygenated benzene $\left(\phi_{\text {fluor }}=0.033\right) .^{2}$ The spectra were normalized by the optical density of the samples at the excitation wavelengths, relative photon intensity of the source and quantum efficiency of the detector throughout the emission range.

A table with absorption data for all newly synthesized porphyrins and metalloporphyrins is given below. In this Table, relative intensities of absorption normalized by the largest absorbance in the spectrum are given in parenthesis, following the positions of the corresponding peaks. ${ }^{3}$ In all the cases reported, the largest absorbances were detected at the B (Soret) bands, whose intensities were set to be 1.0. 


\section{UV-VIS data for porphyrins and metalloporphyrins}

Table 1. ${ }^{\mathrm{a}}$ UV-VIS data for Ar ${ }_{4} \mathrm{TBP}^{\mathrm{S}} \mathrm{s}, \mathrm{Ar}_{4} \mathrm{TCHP}$ 's and their metal complexes

\begin{tabular}{|c|c|c|c|c|c|}
\hline \multicolumn{3}{|r|}{$\mathrm{Ar}_{4} \mathrm{TCHP}$} & \multicolumn{3}{|c|}{$A r_{4} \mathbf{T B P}$} \\
\hline$\#$ & $\begin{array}{l}\mathrm{B}(\text { Soret }) \\
\text { band } \\
\left(\lambda_{\max }, \mathrm{nm}\right)\end{array}$ & $\begin{array}{l}\text { Q bands } \\
\left(\lambda_{\max }, \mathrm{nm}\right)^{\mathrm{b}}\end{array}$ & \# & $\begin{array}{l}\mathrm{B}(\text { Soret }) \\
\text { band } \\
\left(\lambda_{\max }, \mathrm{nm}\right)\end{array}$ & $\begin{array}{l}\mathrm{Q} \text { bands } \\
\left(\lambda_{\max }, \mathrm{nm}\right)^{\mathrm{b}}\end{array}$ \\
\hline $7 \mathbf{a ~ f b}$ & 439 & $537(0.07), 611(0.02), 677(0.01)$ & $8 \mathbf{a ~ f b}$ & 480 & $598(0.07), 647(0.13), 708(0.05)$ \\
\hline $7 \mathbf{a} \mathrm{dc}$ & 455 & $611(0.03), 668(0.09)$ & $8 \mathbf{a} \mathrm{dc}$ & 505 & $649(0.08), 699(0.04)$ \\
\hline $\mathrm{Zn}-7 \mathbf{a}$ & 436 & $565(0.09)$ & Zn-8a & 475 & $620(0.07), 665(0.20)$ \\
\hline $\mathrm{Cu}-7 \mathbf{a}$ & 425 & $557(0.10), 591(0.06)$ & $\mathrm{Cu}-8 \mathrm{a}$ & 474 & $611(0.11), 659(0.34)$ \\
\hline $\mathrm{Ni}-7 \mathbf{a}$ & 425 & $544(0.09), 579(0.08)$ & Ni-8a & 465 & $603(0.10), 655(0.38)$ \\
\hline Pd-7a & 425 & $536(0.10), 368(0.065)$ & Pd-8a & 459 & $589(0.05), 637(0.36)$ \\
\hline $7 \mathbf{b} \mathrm{fb}$ & 445 & $539(0.09), 611(0.04), 675(0.02)$ & $\mathbf{8 b} \mathrm{fb}$ & 480 & $605(0.07), 653(0.14), 711(0.05)$ \\
\hline $7 \mathbf{b} \mathrm{dc}$ & 461 & $611(0.05), 669(0.09)$ & $\mathbf{8 b} \mathrm{dc}$ & 507 & $653(0.12), 706(0.07)$ \\
\hline $\mathrm{Cu}-7 \mathrm{~b}$ & 428 & $559(0.12), 593(0.09)$ & $\mathrm{Cu}-8 \mathrm{~b}$ & 471 & $613(0.11), 662(0.35)$ \\
\hline Ni-7b & 428 & $546(0.08), 581(0.08)$ & $\mathbf{N i - 8 b}$ & 464 & $602(0.10), 656(0.39)$ \\
\hline $7 \mathrm{c} f \mathrm{~b}$ & 442 & $538(0.09), 613(0.03), 681(0.01)$ & $8 c \mathrm{fb}$ & 480 & $601(0.07), 653(0.15), 710(0.05)$ \\
\hline $7 \mathrm{c} \mathrm{dc}$ & 462 & $626(0.04), 677(0.10)$ & $8 \mathrm{c}$ dc & 509 & $653(0.11), 701(0.06)$ \\
\hline $\mathrm{Cu}-7 \mathrm{c}$ & 425 & $559(0.12), 588(0.09)$ & $\mathrm{Cu}-8 \mathrm{c}$ & 472 & $613(0.12), 659(0.37)$ \\
\hline $\mathrm{Ni}-7 \mathrm{c}$ & 426 & $544(0.08), 579(0.07)$ & Ni-8c & 464 & $605(0.08), 657(0.37)$ \\
\hline $7 \mathbf{d} \mathrm{fb}$ & 445 & $540(0.09), 581(0.05), 687(0.02)$ & $8 \mathbf{d} \mathrm{fb}$ & 485 & $598(0.05), 646(0.10), 710(0.02)$ \\
\hline $7 d \mathrm{dc}$ & 471 & $702(0.14)$ & $8 d \mathrm{dc}$ & 529 & $664(0.05), 742(0.03)$ \\
\hline $\mathrm{Cu}-7 \mathrm{~d}$ & 426 & $556(0.12), 590(0.08)$ & $\mathrm{Cu}-8 \mathrm{~d}$ & 480 & $611(0.07), 658(0.29)$ \\
\hline Ni-7d & 426 & $538(0.09), 576(0.08)$ & Ni-8d & 470 & $603(0.06), 654(0.35)$ \\
\hline $7 e \mathrm{fb}$ & 456 & $544(0.12), 610(0.03), 688(0.02)$ & & & \\
\hline $7 e \mathrm{dc}$ & 466 & $613(0.05), 671(0.08)$ & & & \\
\hline $\mathrm{Cu}-7 \mathrm{e}$ & 432 & $564(0.19), 599(0.11)$ & $\mathrm{Cu}-8 \mathrm{e}$ & 469 & $612(0.11), 664(0.37)$ \\
\hline $9 \mathbf{a} \mathrm{fb}$ & 439 & $\begin{array}{l}537(0.10), 580(0.05), 606(0.05) \\
674(0.02)\end{array}$ & & & \\
\hline 9a dc & 464 & $614(0.05), 670(0.09)$ & & & \\
\hline $\mathrm{Cu}-9 \mathrm{a}$ & 424 & $557(0.10), 592(0.06)$ & $\mathrm{Cu}-10 \mathrm{a}$ & 446,458 & $599(0.09), 647(0.42)$ \\
\hline $9 \mathrm{~b} \mathrm{fb}$ & 447 & $\begin{array}{l}538(0.10), 580(0.05), 610(0.05) \\
680(0.02)\end{array}$ & $10 b-f b$ & 467 & $595(0.07), 644(0.15), 701(0.06)$ \\
\hline $9 \mathbf{b} \mathrm{dc}$ & 473 & $618(0.06), 676(0.10)$ & $\mathbf{1 0 b} \mathrm{dc}$ & 498 & $649(0.08), 706(0.09)$ \\
\hline $\mathrm{Cu}-9 \mathrm{~b}$ & 429 & $562(0.12), 597(0.07)$ & $\mathrm{Cu}-10 \mathrm{a}$ & $\begin{array}{l}448 \\
460\end{array}$ & $603(0.09), 652(0.41)$ \\
\hline Ni-9b & 428 & $547(0.10), 584(0.10)$ & Ni-10b & 448 & $596(0.10), 649(0.42)$ \\
\hline Pd-9b & 429 & $540(0.10), 575(0.07)$ & Pd-10b & 433 & $584(0.07), 633(0.37)$ \\
\hline Ni-9a & 424 & $544(0.09), 581(0.09)$ & Ni-10a & 446 & $591(0.08), 643(0.42)$ \\
\hline
\end{tabular}

a Abbreviations: 'fb' - free base, 'dc'-dication. The UV-VIS spectra of $\mathrm{Ar}_{4} \mathrm{TCHP}^{\mathrm{T}} \mathrm{s}$ and $\mathrm{Ar}_{4} \mathrm{TBP}$ 's are very solvent-dependent. Solvents used in our measurements: $\mathrm{Ar}_{4} \mathrm{TCHP}(\mathrm{fb}): \mathrm{CH}_{2} \mathrm{Cl}_{2}-\mathrm{Et}_{3} \mathrm{~N}(9: 1) ; \mathrm{Ar}_{4} \mathrm{TCHP}$ 9a,b (dc) chlorides: $\mathrm{CH}_{2} \mathrm{Cl}_{2} ; \mathrm{Ar}_{4} \mathrm{TCHP}$ 7a-e (dc) and $\mathrm{Ar}_{4} \mathrm{TBP}(\mathrm{dc}): \mathrm{CH}_{2} \mathrm{Cl}_{2}-\mathrm{TFA}$ (9:1). All the other compounds: $\mathrm{CH}_{2} \mathrm{Cl}_{2}$.

b Numbers in parentheses show relative intensities of absorption normalized by the largest absorbance in the spectrum. In all the cases reported, the largest absorbances were detected at the B (Soret) bands, whose intensities were set to be 1.0 . 


\section{X-ray Structure Determination}

Compound $\mathrm{Ni}-8 \mathrm{a}, \mathrm{NiC}_{77} \mathrm{H}_{53} \mathrm{~N}_{6} \mathrm{O}_{16} \mathrm{Cl}_{3}$, crystallizes in the tetragonal space group

$\mathrm{P} \overline{4} 2_{1} \mathrm{c}$ (systematic absences $\mathrm{h} 00: \mathrm{h}=$ odd and hhl: $\mathrm{l}=\mathrm{odd}$ ) with $\mathrm{a}=20.8569(4) \AA$, $\mathrm{c}=9.0442(2) \AA, \mathrm{V}=3934.32(14) \AA^{3}, \mathrm{Z}=2$ and $\mathrm{d}_{\text {calc }}=1.228 \mathrm{~g} / \mathrm{cm}^{3}$. X-ray intensity data were collected on a Rigaku R-AXIS IIc area detector employing graphite-monochromated Mo$\mathrm{K}_{\alpha}$ radiation $(\lambda=0.71069 \AA)$ at a temperature of $180^{\circ} \mathrm{K}$. Indexing was performed from a series of $1^{\circ}$ oscillation images with exposures of 100 seconds per frame. A hemisphere of data was collected using $5^{\circ}$ oscillation angles with exposures of 500 seconds per frame and a crystal-to-detector distance of $82 \mathrm{~mm}$. Oscillation images were processed using bioteX, ${ }^{4}$ producing a listing of unaveraged $\mathrm{F}^{2}$ and $\sigma\left(\mathrm{F}^{2}\right)$ values which were then passed to the teXsan ${ }^{5}$ program package for further processing and structure solution on a Silicon Graphics Indigo R4000 computer. A total of 12758 reflections were measured over the ranges $5.52 \leq 2 \theta \leq 50.7^{\circ},-25 \leq \mathrm{h} \leq 22,-25 \leq \mathrm{k} \leq 23,-10 \leq 1 \leq 9$ yielding 3556 unique reflections $\left(\mathrm{R}_{\text {int }}=0.0432\right)$. The intensity data were corrected for Lorentz and polarization effects but not for absorption.

The structure was solved by direct methods (SIR92). ${ }^{6}$ The Ni porphyrin lies on a crystallographic $\overline{4}$ axis. Thus the asymmetric consists of $1 /{ }_{4}$ of the Ni complex plus 0.80

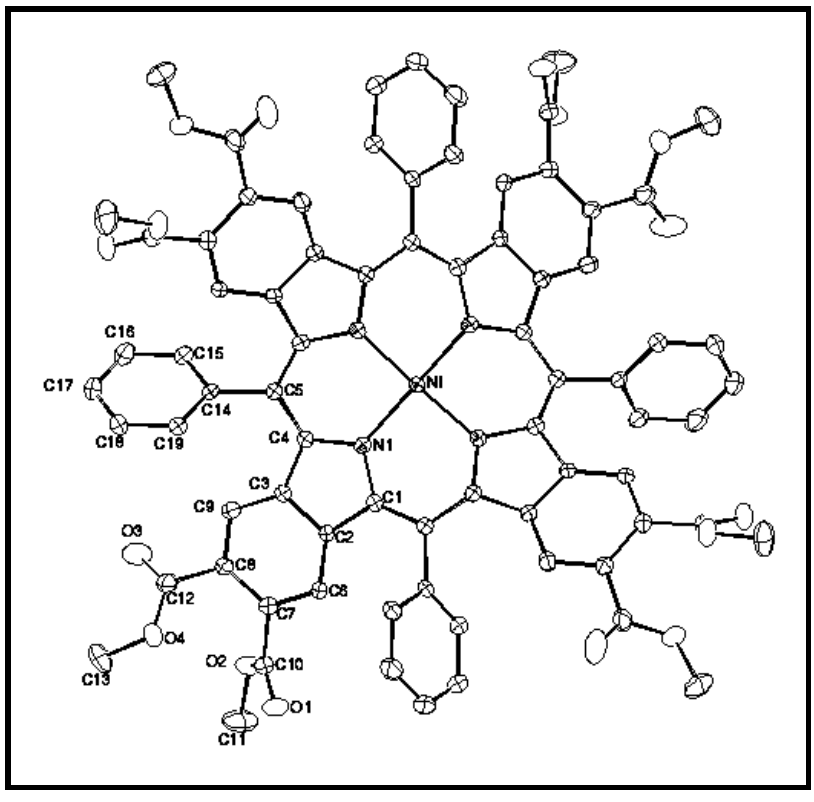

Figure S1. ORTEP drawing of the title compound with $30 \%$ probability thermal ellipsoids. of a $\mathrm{CHCl}_{3}$ molecule; the population of the $\mathrm{CHCl}_{3}$ molecule refined to 0.805(6). Refinement was done by full-matrix least squares based on $\mathrm{F}^{2}$ using SHELXL-93. 7 All reflections were used during refinement $\left(\mathrm{F}^{2}\right.$ 's that were experimentally negative were replaced by $\mathrm{F}^{2}=0$ ). The weighting scheme used was $\mathrm{w}=1 /\left[\sigma^{2}\left(\mathrm{~F}_{\mathrm{o}}^{2}\right)+0.0852 \mathrm{P}^{2}+3.6662 \mathrm{P}\right]$ where $\mathrm{P}=\left(\mathrm{F}_{\mathrm{o}}^{2}+2 \mathrm{~F}_{\mathrm{c}}^{2}\right) / 3$. Nonhydrogen atoms were refined anisotropically and hydrogen atoms were refined using a "riding" model. Refinement converged to $\mathrm{R}_{1}=0.0617$ and $\mathrm{wR}_{2}=0.1583$ for 3301 reflections for which $\mathrm{F}>4 \sigma(\mathrm{F})$ and $\mathrm{R}_{1}=0.0662$, $\mathrm{wR}_{2}=0.1623$ and $\mathrm{GOF}=1.068$ for all 3556 unique, non-zero reflections and 258 variables. ${ }^{8}$ The maximum

$\Delta / \sigma$ in the final cycle of least squares was 0.001 and the two most prominent peaks in the final difference Fourier were +0.521 and $-0.540 \mathrm{e} / \AA^{3}$.

ORTEP $^{9}$ representation of the molecule with $30 \%$ probability thermal ellipsoids is shown in Figure 1. Table 2 lists cell information, data collection parameters, and refinement data. 
Table 2. Summary of Structure Determination of Compound Ni-8a

Formula:

Formula weight:

Crystal class:

Space group:

Z

Cell constants:

a

c

$\mathrm{V}$

$\mu$

crystal size, $\mathrm{mm}$

$\mathrm{D}_{\text {calc }}$

$\mathrm{F}(000)$

Radiation:

$2 \theta$ range

hkl collected:

$10 \leq 1 \leq 9$

No. reflections measured:

No. unique reflections:

No. observed reflections

No. reflections used in refinement

No. parameters

$R$ indices $(F>4 \sigma)$

$\mathrm{R}$ indices (all data)

GOF:

Final Difference Peaks, e/ $\AA^{3}$
$\mathrm{NiC}_{77} \mathrm{H}_{53} \mathrm{~N}_{6} \mathrm{O}_{16} \mathrm{Cl}_{3}$

1455.29

tetragonal

$\mathrm{P} \overline{4} 2{ }_{1} \mathrm{c}(\# 114)$

2

$20.8569(4) \AA$

$9.0442(2) \AA$

$3934.32(14) \AA^{3}$

$4.13 \mathrm{~cm}^{-1}$

$0.30 \times 0.15 \times 0.13$

$1.228 \mathrm{~g} / \mathrm{cm}^{3}$

1500

Mo- $\mathrm{K}_{\alpha}(\lambda=0.71069 \AA)$

$5.52-50.7^{\circ}$

$-25 \leq \mathrm{h} \leq 22 ;-25 \leq \mathrm{k} \leq 23$; -

12758

$3556\left(\mathrm{R}_{\text {int }}=0.0432\right)$

$3301(\mathrm{~F}>4 \sigma)$

3556

258

$\mathrm{R}_{1}=0.0617$

$\mathrm{wR}_{2}=0.1583$

$\mathrm{R}_{1}=0.0662$

$\mathrm{wR}_{2}=0.1623$

1.068

$+0.521,-0.540$ 


\section{Normal Coordinate Structural Decomposition (NSD) analysis}

NSD analysis of the structure of Ni-8a was accomplished using the web-based NSD program. ${ }^{10}$ The results of the complete NSD decomposition are given below.



\section{Computational Data}

Quantum chemistry calculations of the cation radical $\mathrm{H}_{2} \mathrm{Ph}_{4} \mathrm{TCHP}^{+\bullet}$ were performed using $G 98 W$ (Gaussian 98 for Windows) ${ }^{11}$ from Gaussian Inc. (Pittsburgh, $\mathrm{PA}$ ) running on a $2.5 \mathrm{GHz} \mathrm{PC}$. At first, the ground state structure of the parent compound, $\mathrm{H}_{2} \mathrm{Ph}_{4} \mathrm{TCHP}$, was optimized using B3LYP/6-31G model chemistry, beginning with AM1-optimized structure. Using thus determined geometry as the starting point for the UHF calculations, the structure of the corresponding cation-radical was optimized at B3LYP/6-31G level. The maps of the unpaired spin density $(\alpha-\beta$ spin) and the plots of the molecular orbitals were generated using $G 98$ Cubegen utility and visualized using gOpenMol software. ${ }^{12}$

A

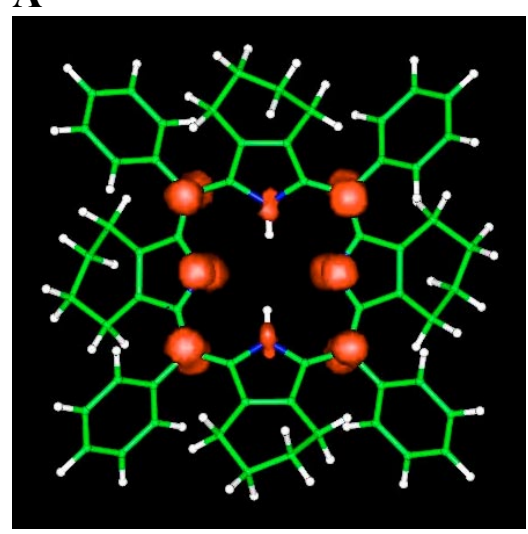

B

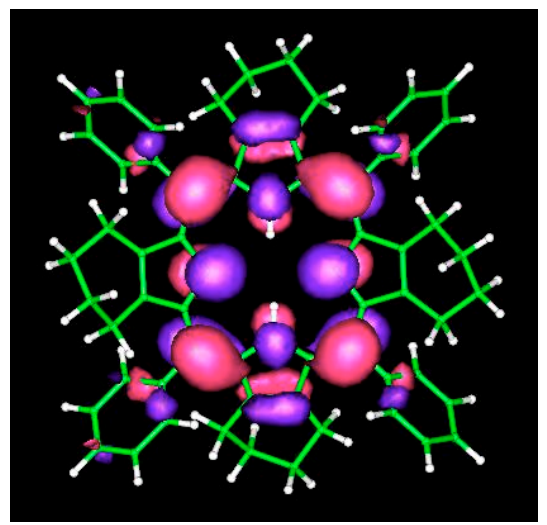

Figure S2. A) Distribution of the spin density in the cation-radical $\mathrm{H}_{2} \mathrm{Ph}_{4} \mathrm{TCHP}^{+\bullet}$; B) $\mathrm{a}_{2 \mathrm{u}}(\pi)$ HOMO in the free base $\mathrm{H}_{2} \mathrm{Ph}_{4} \mathrm{TCHP}$. 


\section{References and Notes}

(1) Vinogradov, S. A.; Fernandez-Seara, M. A.; Dugan, B. W.; Wilson, D. F. Rev. Sci. Instrum. 2001, $72,3396$.

(2) Quimby, D. J.; Longo, F. R. J. Am. Chem. Soc. 1975, 97, 5111.

(3) We found that this way of presenting UV-VIS data for porphyrins is superior to more traditional reporting of the molecular extinction coefficients, unless these are determined using special accurate methods. Porphyrins and especially tetrabenzoporphyrins always retain non-stoichiometric amounts of solvents in their crystal lattices, which lead to large errors in the molar quantities determined by weighting of solid materials. Considering extremely large absolute molar extinctions of porphyrins, these errors lead to very large absolute errors in the derived extinction coefficients. On the other hand, relative oscillator strengths do not require precise determination of molar quantities, and therefore are not bound to such errors.

(4) bioteX: A suite of Programs for the Collection, Reduction and Interpretation of Imaging Plate Data, Molecular Structure Corporation (1995).

(5) teXsan: Crystal Structure Analysis Package, Molecular Structure Corporation (1985 \& 1992).

(6) SIR92: Altomare, A., Burla, M.C., Camalli, M., Cascarano, M., Giacovazzo, C., Guagliardi, A., Polidoro, G. (1994). J. Appl. Cryst., 27, 435.

(7) SHELXL-93: Program for the Refinement of Crystal Structures, Sheldrick, G.M. (1993), University of Göttingen, Germany.

(8) $\quad \mathrm{R}_{1}=\sum|| \mathrm{F}_{\mathrm{O}}|-| \mathrm{F}_{\mathrm{c}} \| / \sum\left|\mathrm{F}_{\mathrm{O}}\right|$ $\mathrm{wR}_{2}=\left\{\sum \mathrm{w}\left(\mathrm{F}_{\mathrm{o}}^{2}-\mathrm{F}_{\mathrm{c}}^{2}\right)^{2} / \sum \mathrm{w}\left(\mathrm{F}_{\mathrm{o}}^{2}\right)^{2}\right\}^{1 / 2}$

$\mathrm{GOF}=\left\{\sum \mathrm{w}\left(\mathrm{F}_{\mathrm{o}}^{2}-\mathrm{F}_{\mathrm{c}}^{2}\right)^{2} /(\mathrm{n}-\mathrm{p})\right\}^{1 / 2}$

where $\mathrm{n}=$ the number of reflections and $\mathrm{p}=$ the number of parameters refined.

(9) "ORTEP-II: A Fortran Thermal Ellipsoid Plot Program for Crystal Structure Illustrations". C.K. Johnson (1976) ORNL-5138.

(10) http://jasheln.unm.edu/ NSD references: (a) W. Jentzen, X.-Z. Song, J. A. Shelnutt, J. Phys.Chem. B 1997, 101, 1684-1699; (b) W. Jentzen, J. G. Ma, J. A. Shelnutt, Biophys. J. 1998, 74, 753-763; For reviews see: (c) J. Shelnutt, Molecular simulations and normal-coordinate structural analysis of porphyrins and heme proteins, Ch. 50 in The Porphyrin Handbook, K. M. Kadish, K. M. Smith, R. Guilard, Eds., Academic Press, 2000; (d) J. A. Shelnutt, J. Porph. Phthal. 2001, 5, 300-311.

(11) Gaussian 98, Revision A.11.2, M. J. Frisch, G. W. Trucks, H. B. Schlegel, G. E. Scuseria, M. A. Robb, J. R. Cheeseman, V. G. Zakrzewski, J. A. Montgomery, Jr., R. E. Stratmann, J. C. Burant, S. Dapprich, J. M. Millam, A. D. Daniels, K. N. Kudin, M. C. Strain, O. Farkas, J. Tomasi, V. Barone, M. Cossi, R. Cammi, B. Mennucci, C. Pomelli, C. Adamo, S. Clifford, J. Ochterski, G. A. Petersson, P. Y. Ayala, Q. Cui, K. Morokuma, N. Rega, P. Salvador, J. J. Dannenberg, D. K. Malick, A. D. Rabuck, K. Raghavachari, J. B. Foresman, J. Cioslowski, J. V. Ortiz, A. G. Baboul, B. B. Stefanov, G. Liu, A. Liashenko, P. Piskorz, I. Komaromi, R. Gomperts, R. L. Martin, D. J. Fox, T. Keith, M. A. Al-Laham, C. Y. Peng, A. Nanayakkara, M. Challacombe, P. M. W. Gill, B. Johnson, W. Chen, M. W. Wong, J. L. Andres, C. Gonzalez, M. Head-Gordon, E. S. Replogle, and J. A. Pople, Gaussian, Inc., Pittsburgh PA, 2001.

(12) (a) L. Laaksonen, J. Mol. Graphics, 1992, 10, 33; (b) D.L. Bergman, L. Laaksonen and A. Laaksonen, J. Mol. Graphics \& Modeling, 1997, 15, 301. 
NMR spectra 


\section{Pyrroles}




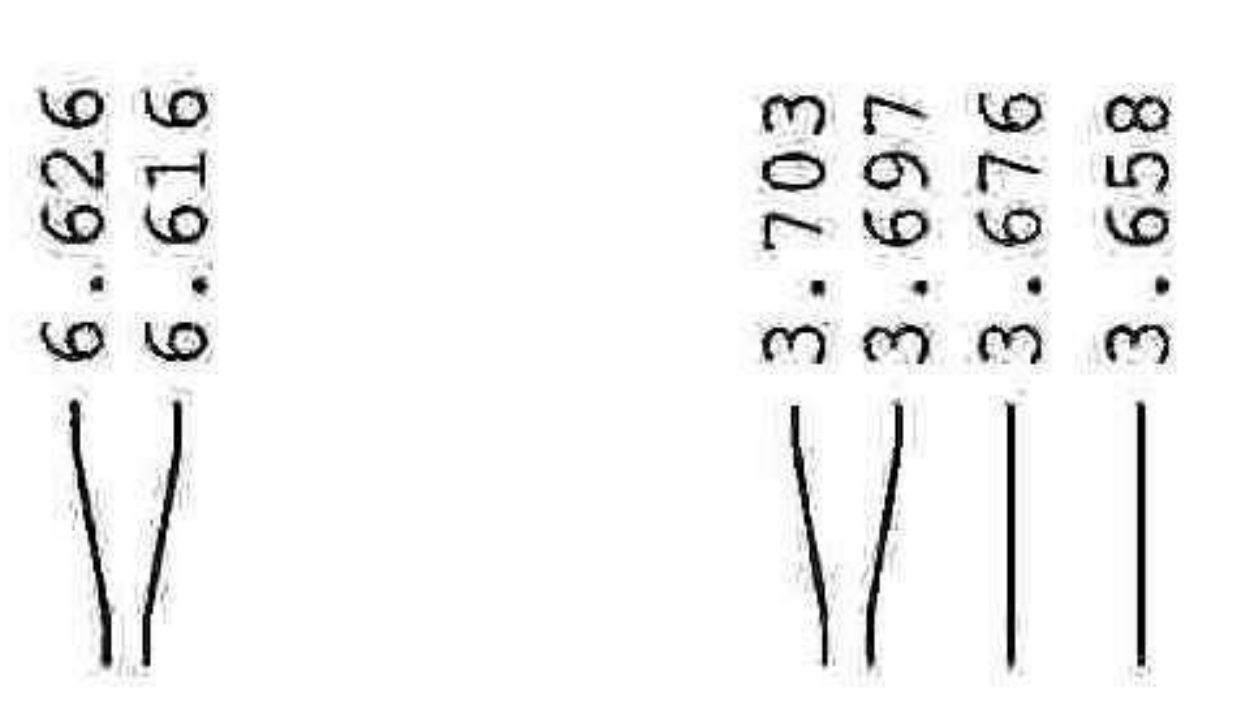

\section{5a-trans}
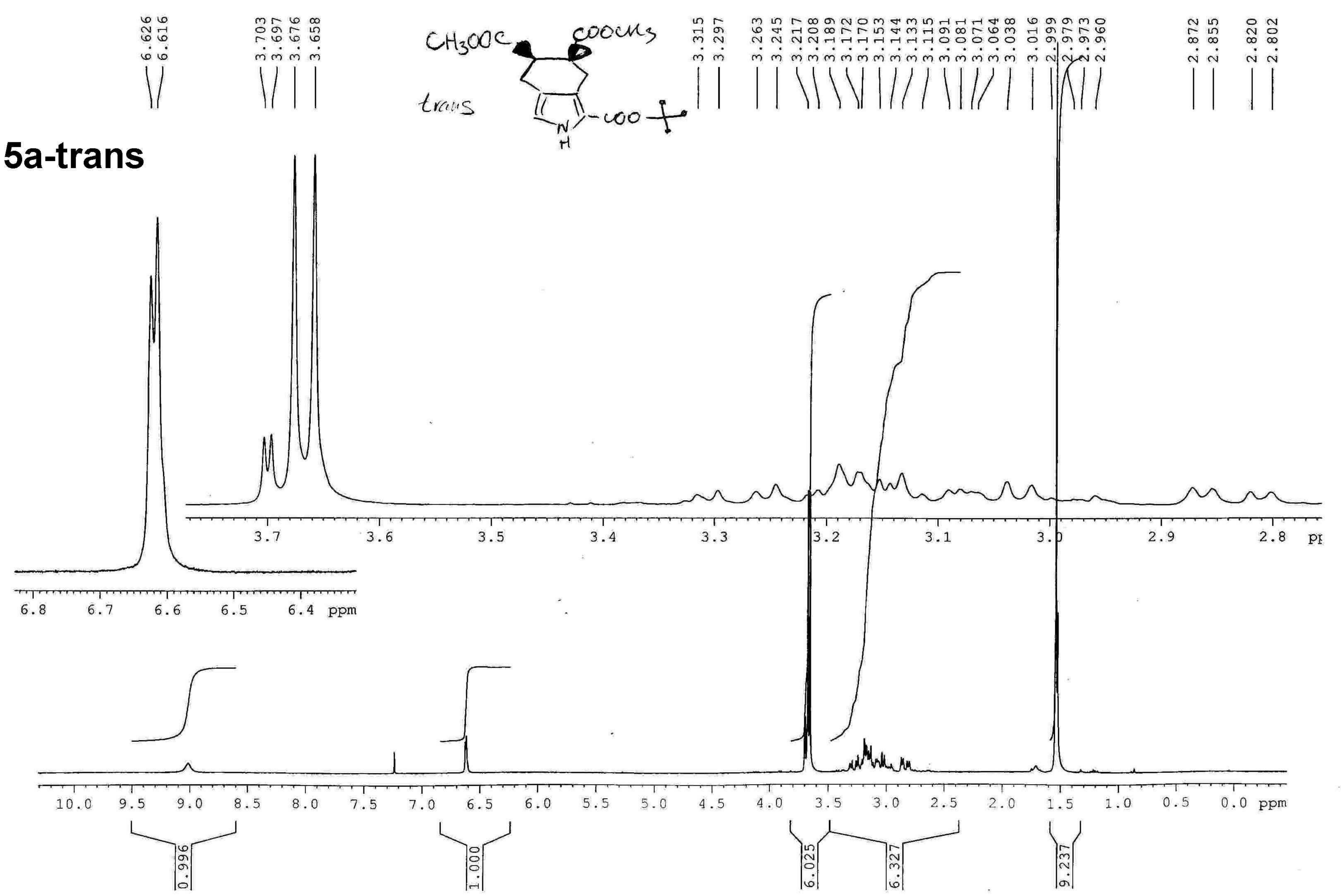







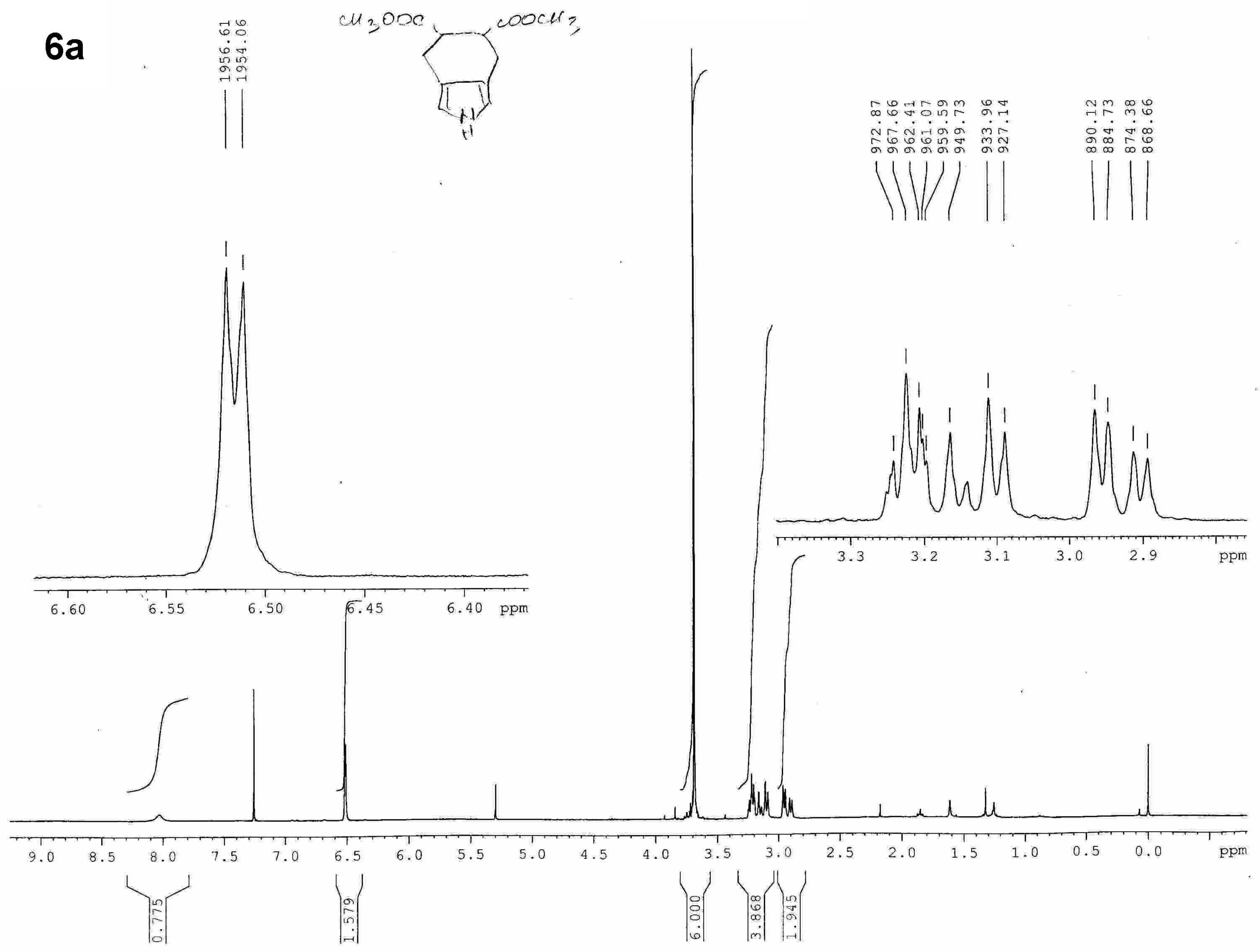




\section{II. $\mathrm{Ar}_{4} \mathrm{TCHP}$}




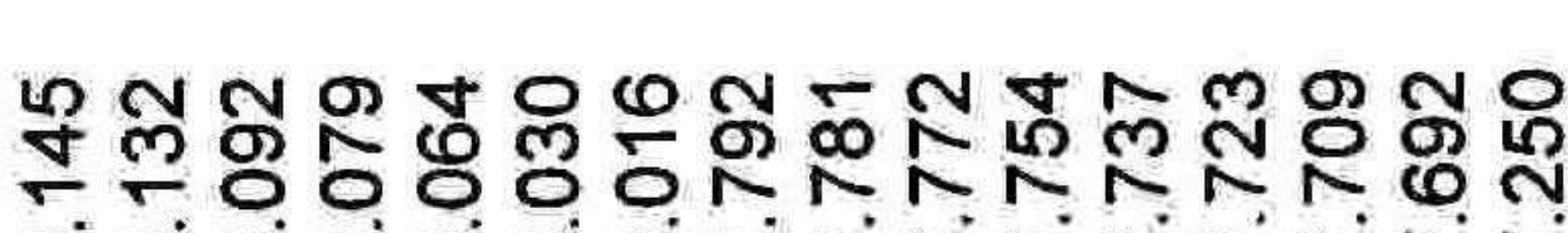


$\infty \infty \infty \infty \infty \infty \pi N \wedge N \wedge N$ W N $+1$

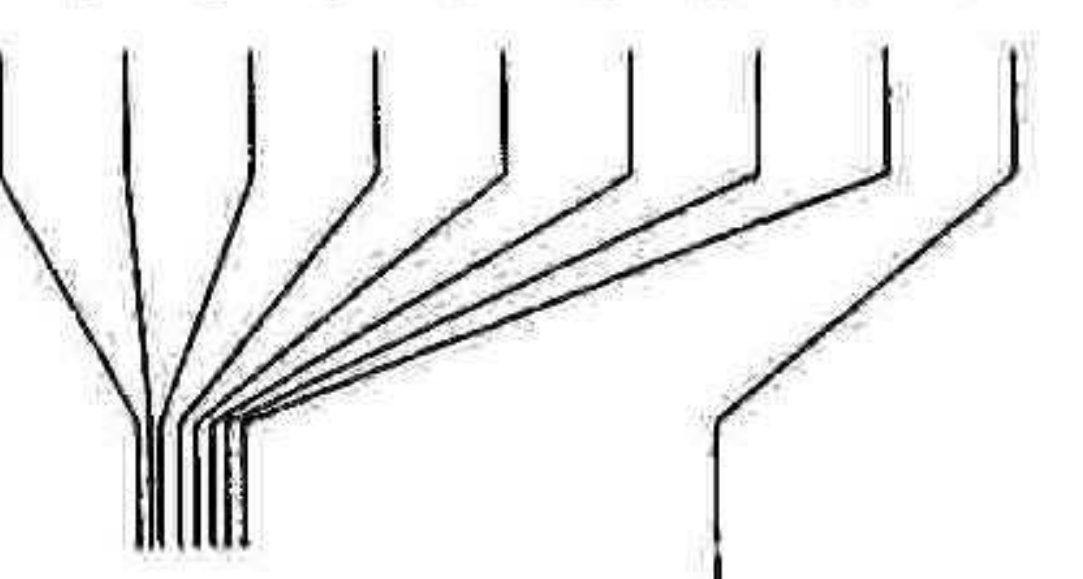
बां

Pd-7a

$\mathrm{CuCl}_{3}$

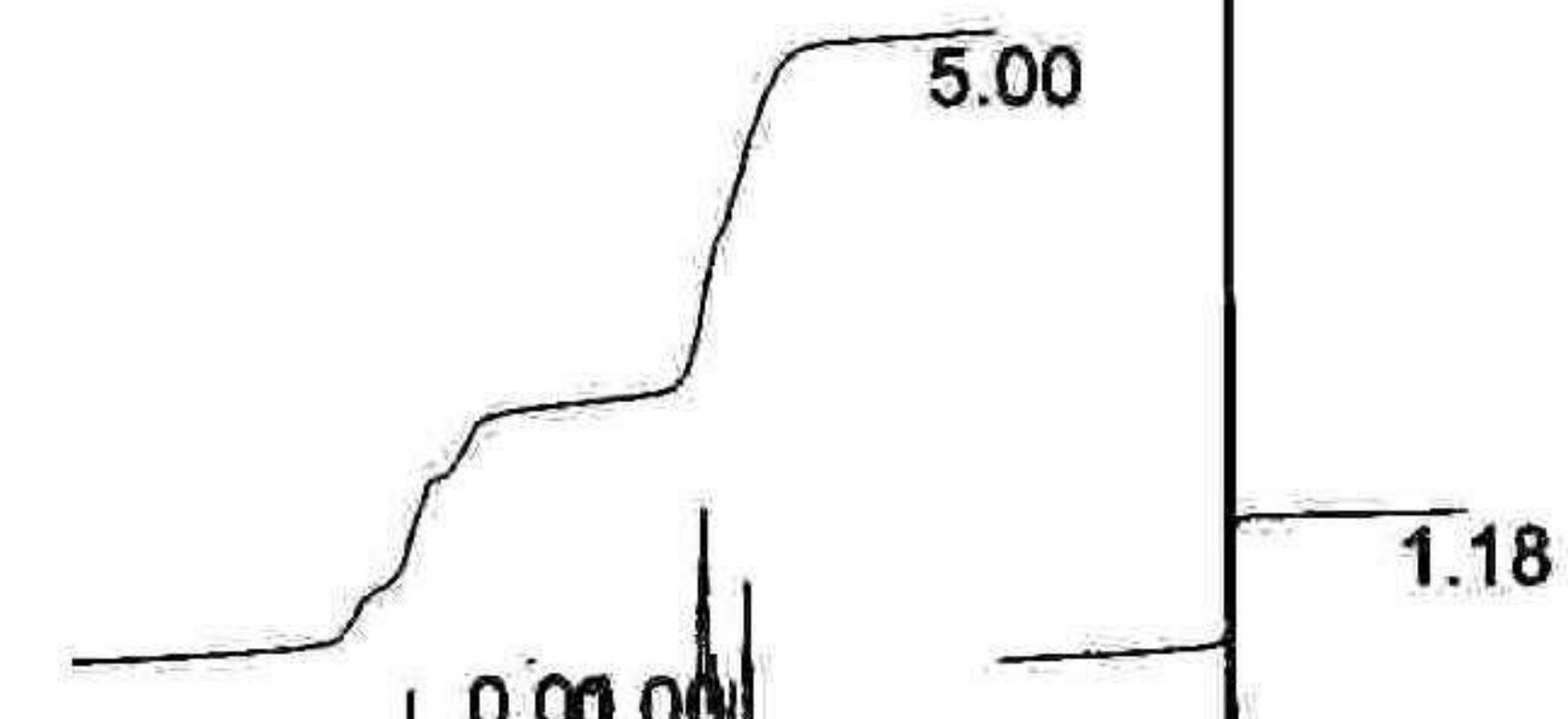

$\mathrm{CH}_{2} \mathrm{Cl}_{2}$

0.42
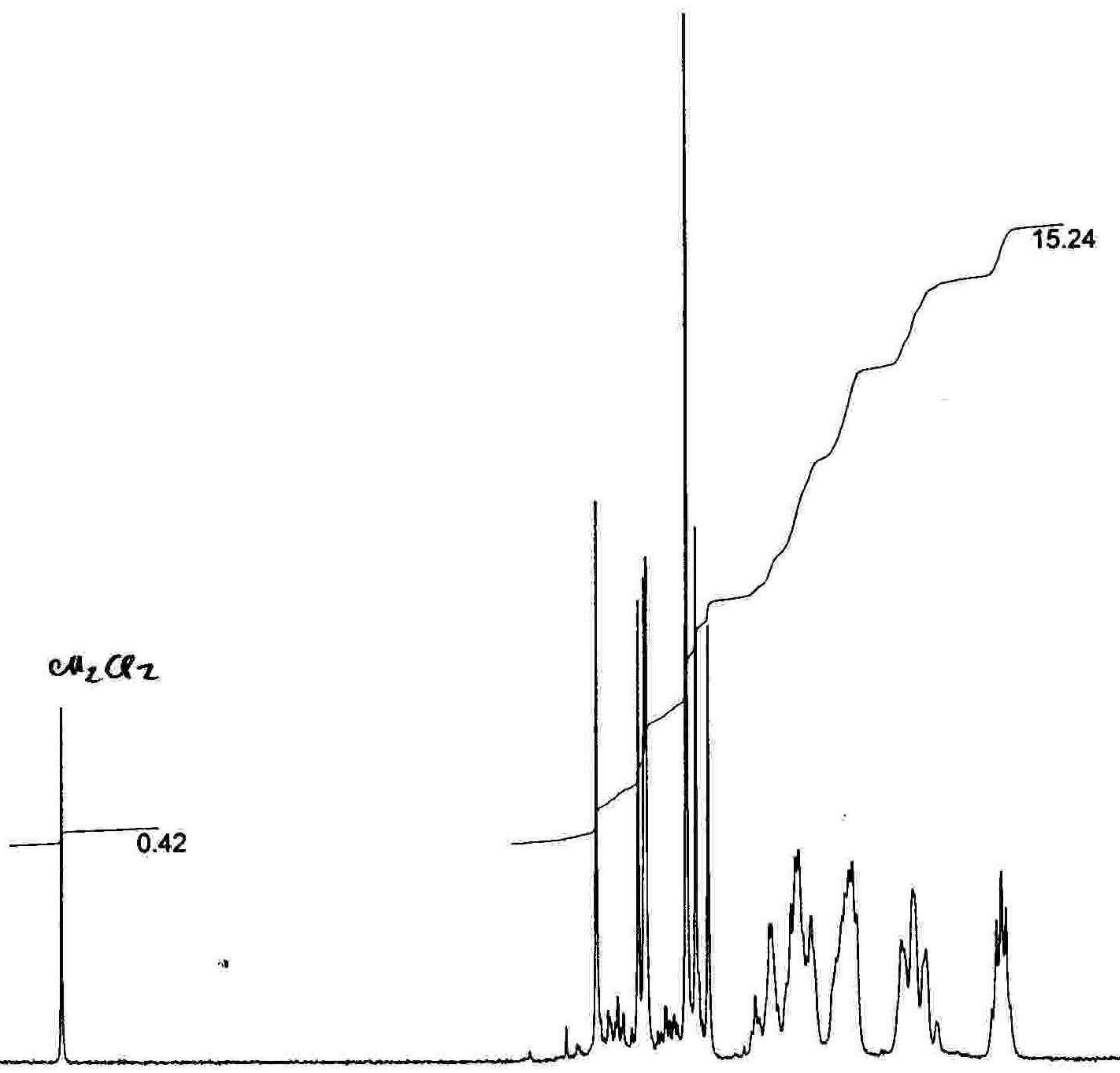


\section{Zn-7a}

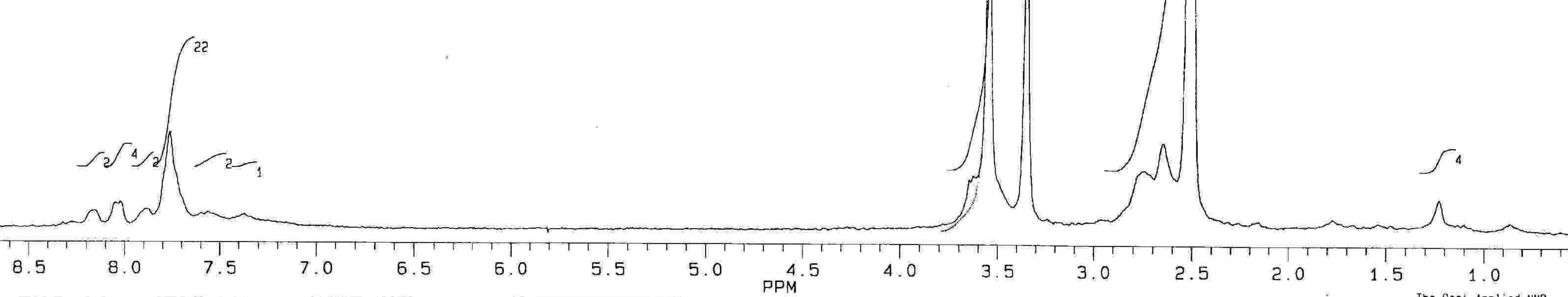




\section{7d (free base)}

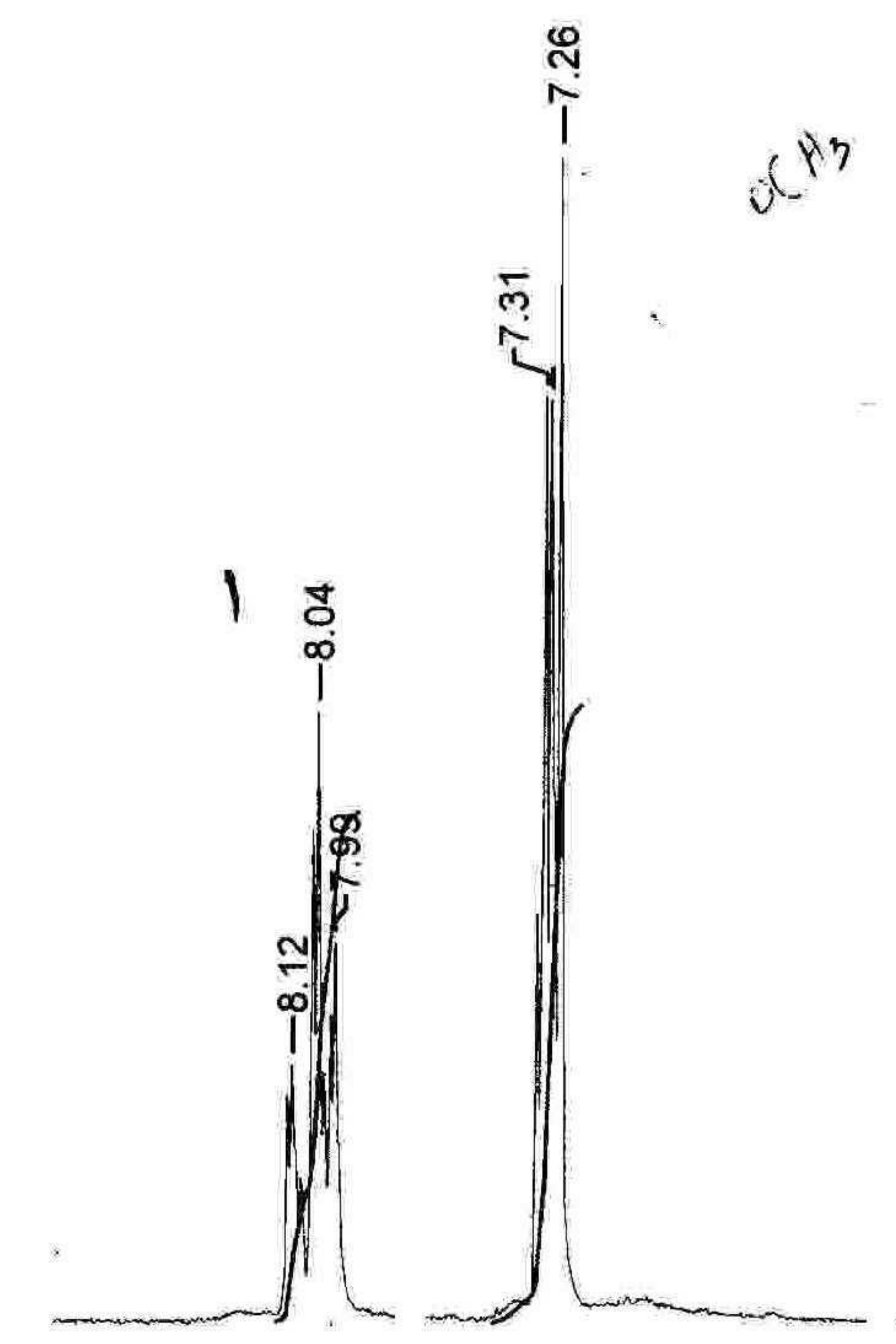

$\stackrel{\circ}{\div}$

$3.60 \quad 4.35$

6.00

23.15



\section{9a (dication)}


CDCl3-TFA



120

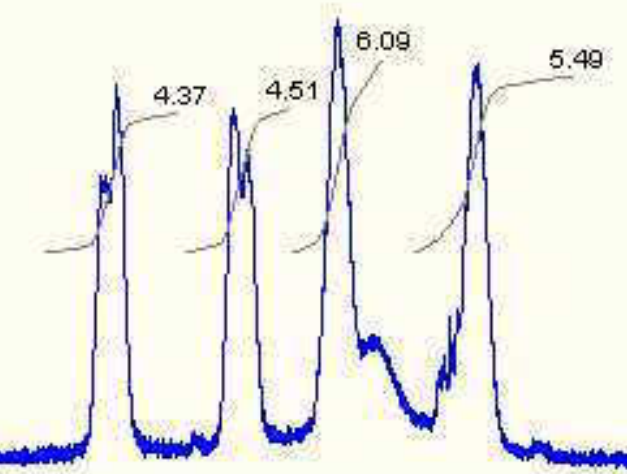




\section{Ni-9a}

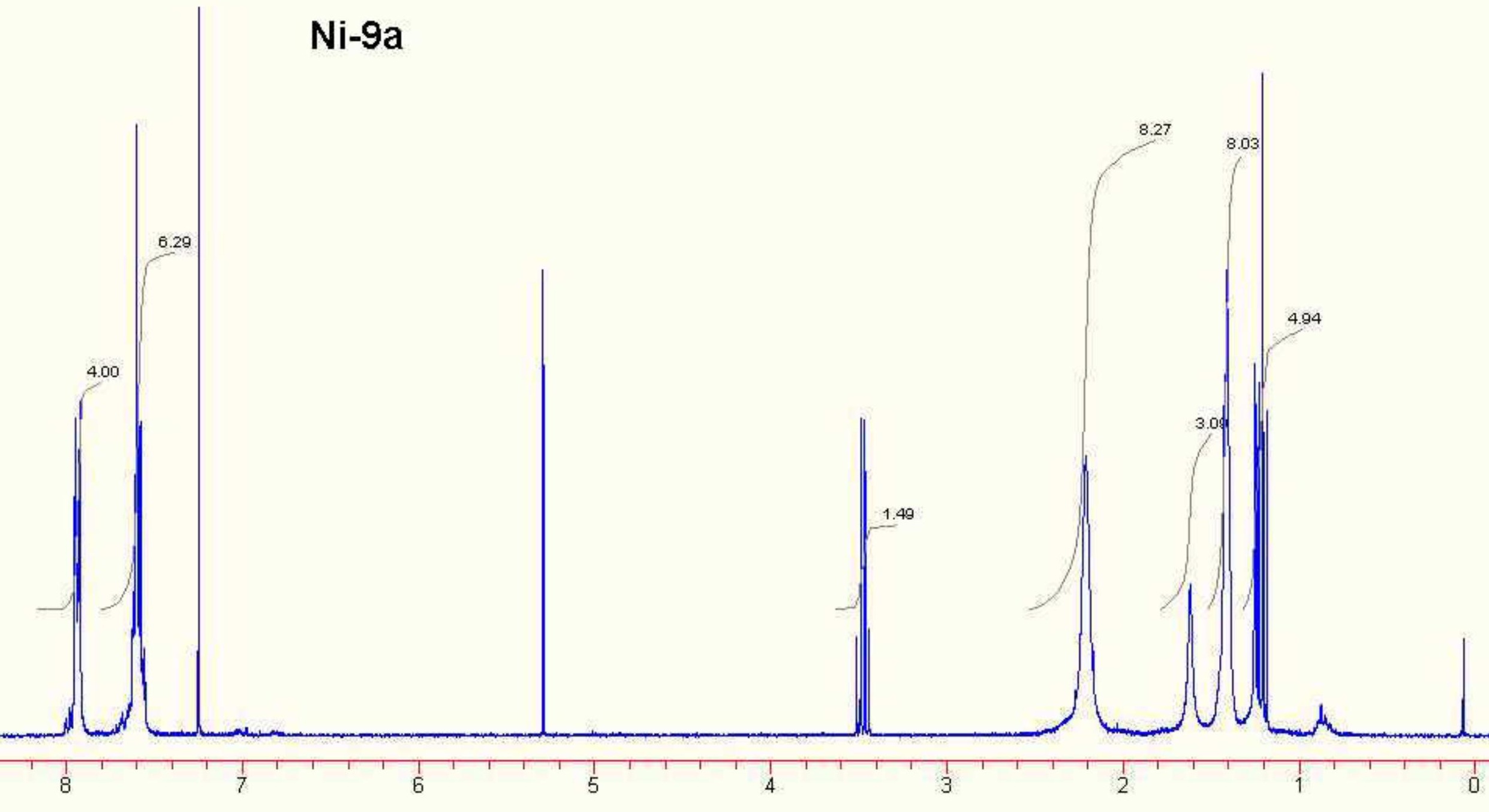




\section{$9 b$ (dication) ${ }^{13} \mathrm{C}$}

CDCI3-TFA

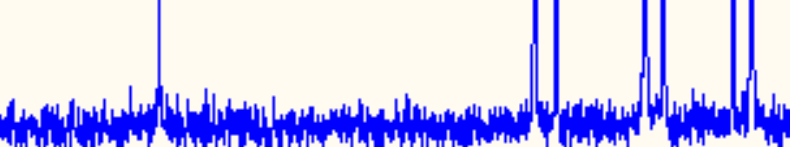




\section{Pd-9b 13C}

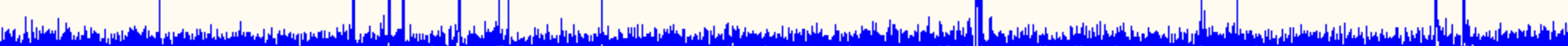






\section{III. $\mathrm{Ar}_{4} \mathrm{TBP}$}




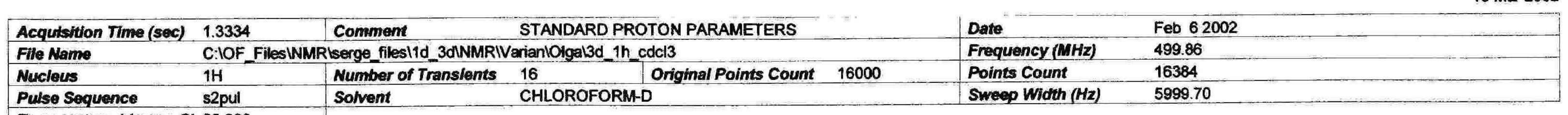

\begin{tabular}{|ll|}
\hline Pulse Sequence & s2pul \\
\hline Temperature (degree C) 25.000
\end{tabular} Solvent CHLOROFORM-D

Sweep Width (Mz) $\quad 5999.70$

\section{8a (dication) CDCI3-TFA}

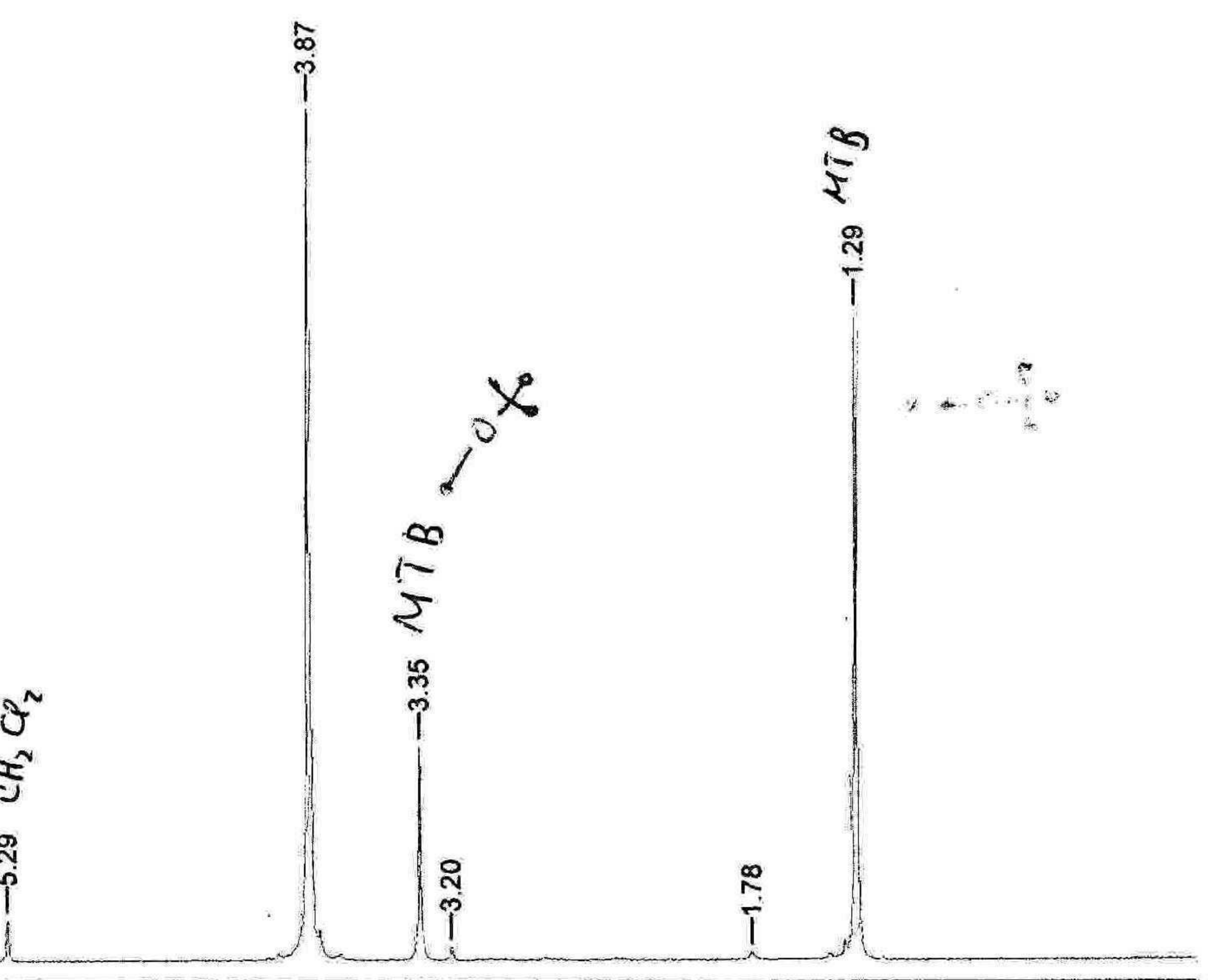

\begin{tabular}{|c|c|c|c|c|c|c|c|}
\hline No. & (ppm) & $(\mathrm{Hz})$ & Height & No. & (ppm) & $(\mathrm{Hz})$ & Height \\
\hline 1 & 1.29 & 645.0 & 0.7570 & 10 & 8.04 & 4016.4 & 0.1809 \\
\hline 2 & 1.78 & 890.0 & 0.0081 & 11 & 8.05 & 4023.7 & 0.1254 \\
\hline 3 & 3.20 & 1597.9 & 0.0150 & 12 & 8.11 & 4056.3 & 0.0678 \\
\hline 4 & 3.35 & 1672.6 & 0.2505 & 13 & 8.13 & 4063.3 & 0.0844 \\
\hline 5 & 3.87 & 1935.2 & 1.0000 & 14 & 8.14 & 4069.8 & 0.0411 \\
\hline 6 & 5.29 & 2645.3 & 0.0472 & 15 & 8.49 & 4244.9 & 0.1755 \\
\hline 7 & 7.26 & 3629.3 & 0.0267 & 16 & 8.51 & 4251.5 & 0.1676 \\
\hline 8 & 7.79 & 3893.0 & 0.2907 & 17 & 10.96 & 5480.5 & 0.0827 \\
\hline 9 & 8.02 & 4009.4 & 0.1025 & & & & \\
\hline
\end{tabular}



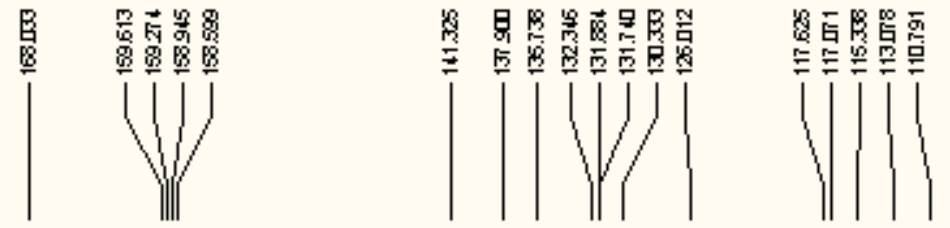

\section{8 a (dication) $13 \mathrm{C}$ CDCl3-TFA}

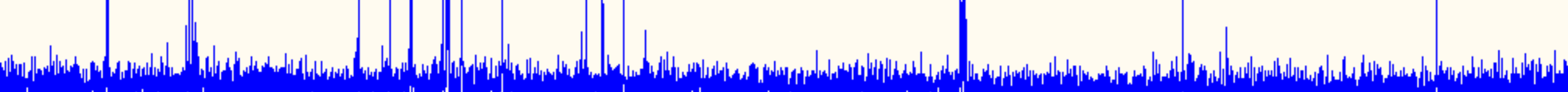

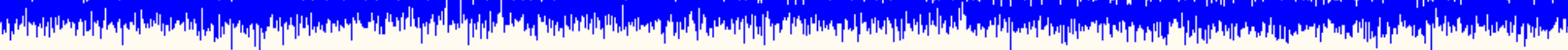




\section{$\mathrm{Zn-8a}$}

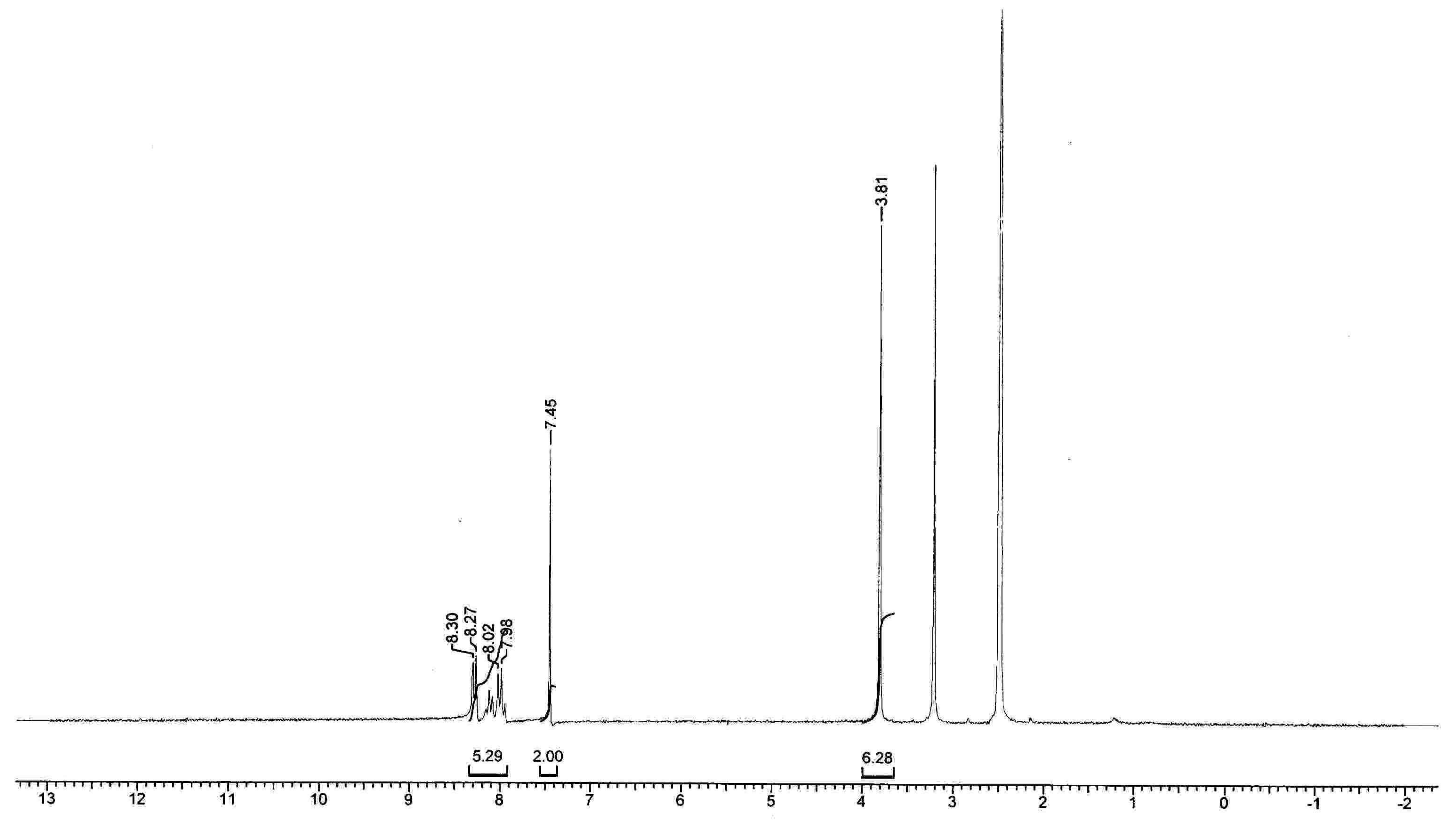




\section{$\mathrm{Ni}-8 \mathrm{a}$}









Pd-8a

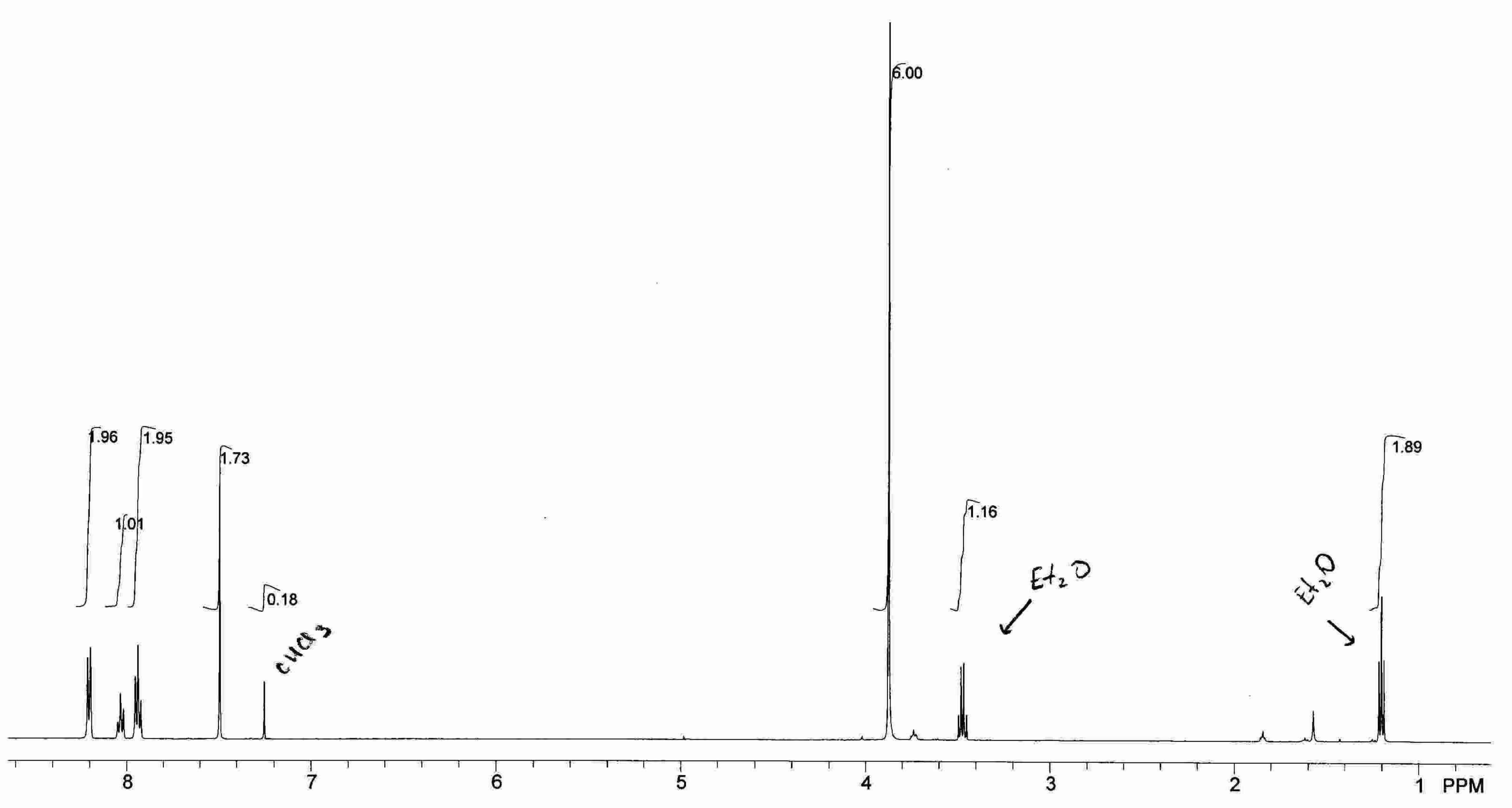






Pd-8a 13C
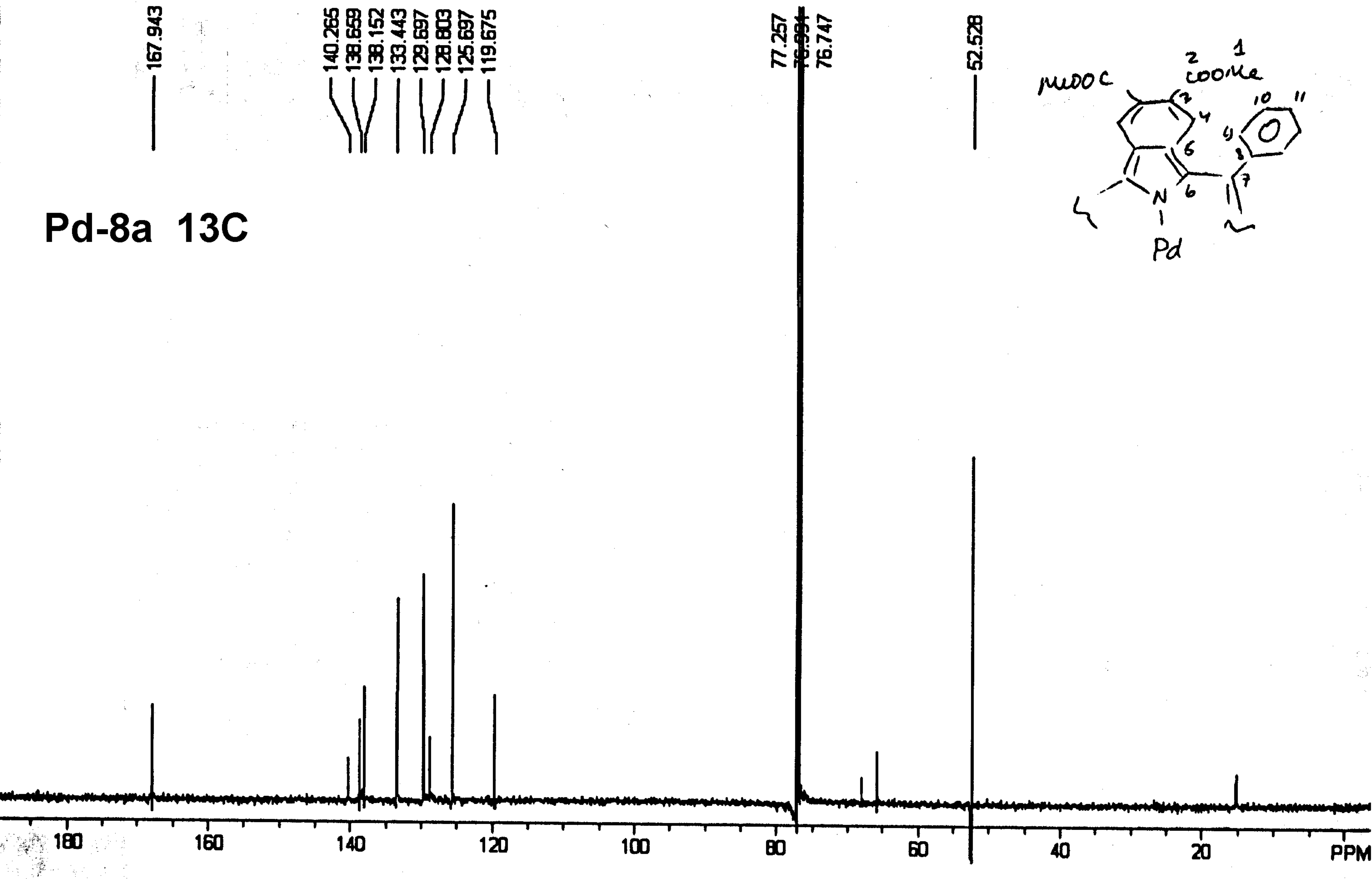


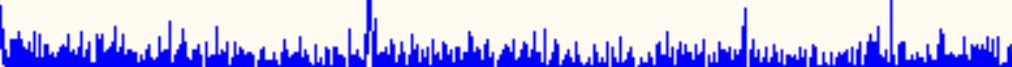

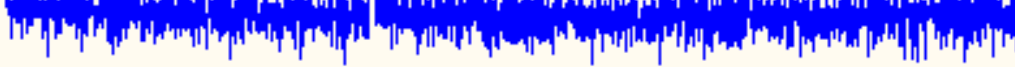


Ni-8b

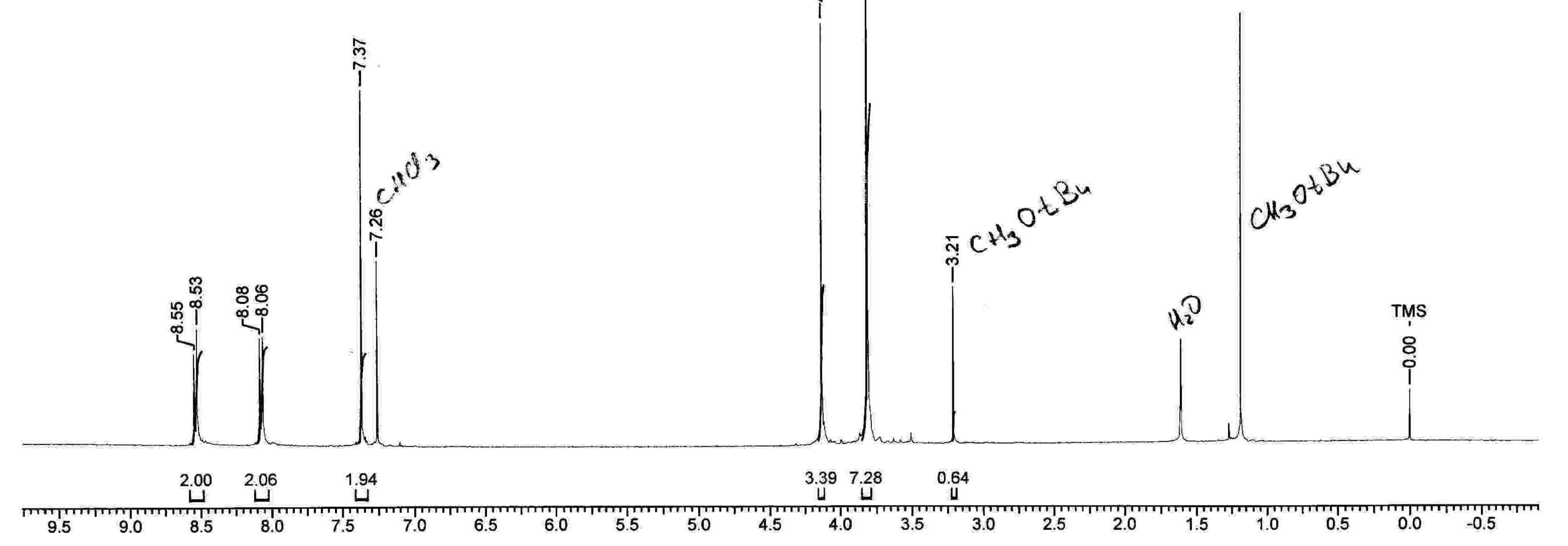




\section{Ni-8b $13 C$}

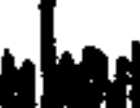

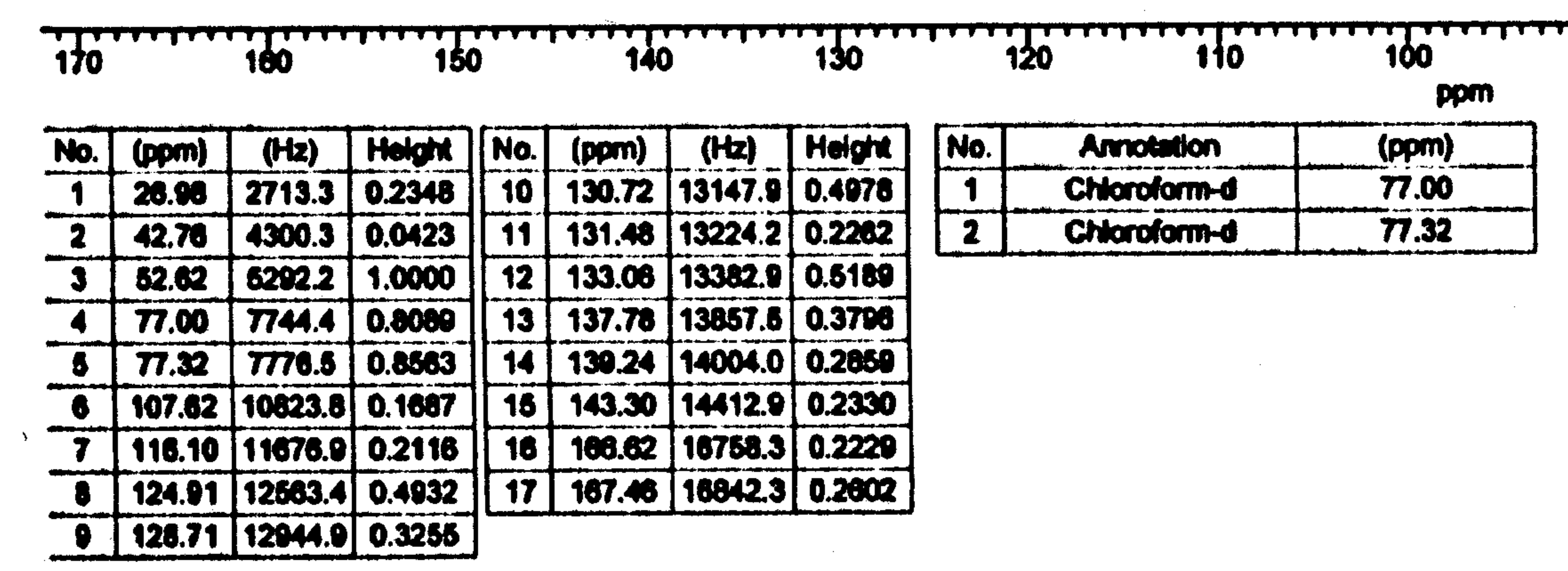




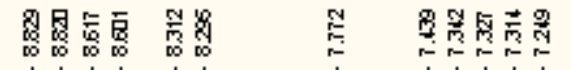

$\left.\left.1\right|^{\infty}\right|^{\infty}||^{\infty} \mid$

$\stackrel{\frac{10}{8}}{\frac{10}{5}}$

Pd-8b

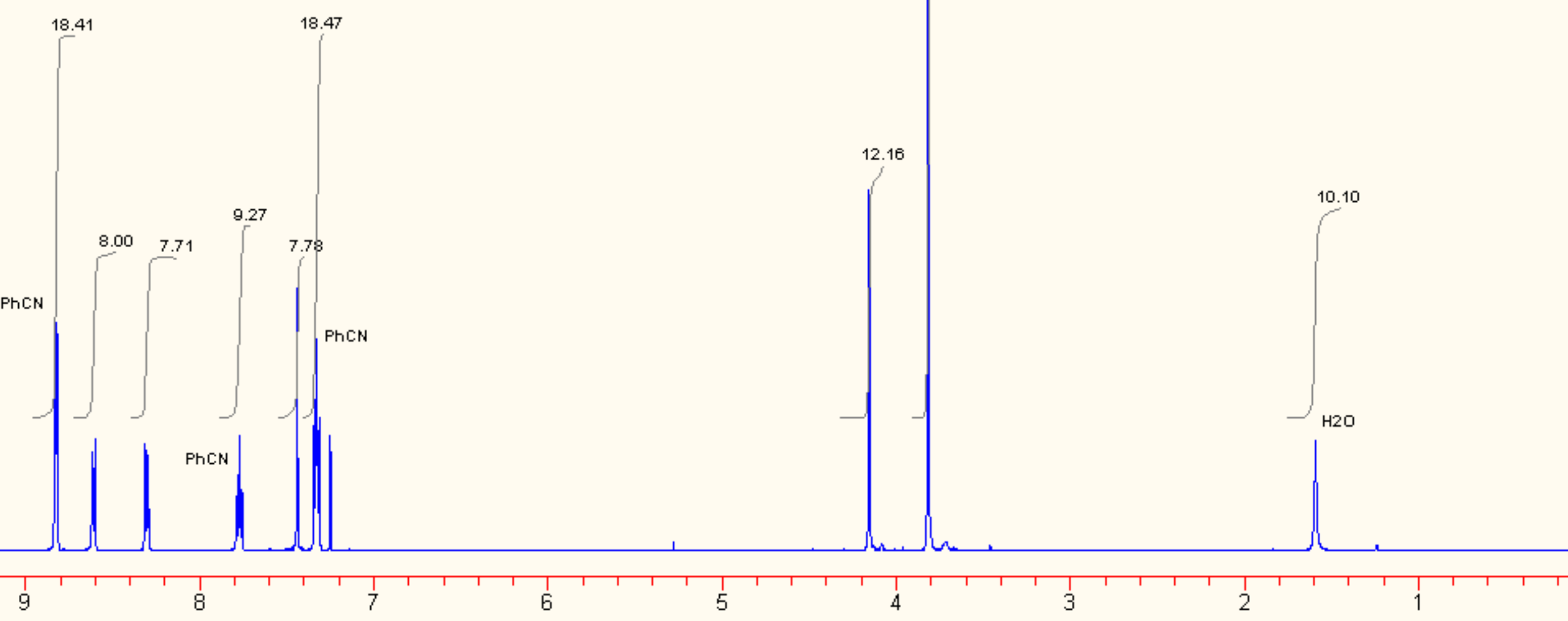


8c

(dication)

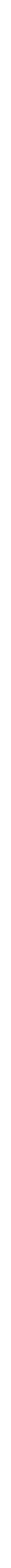




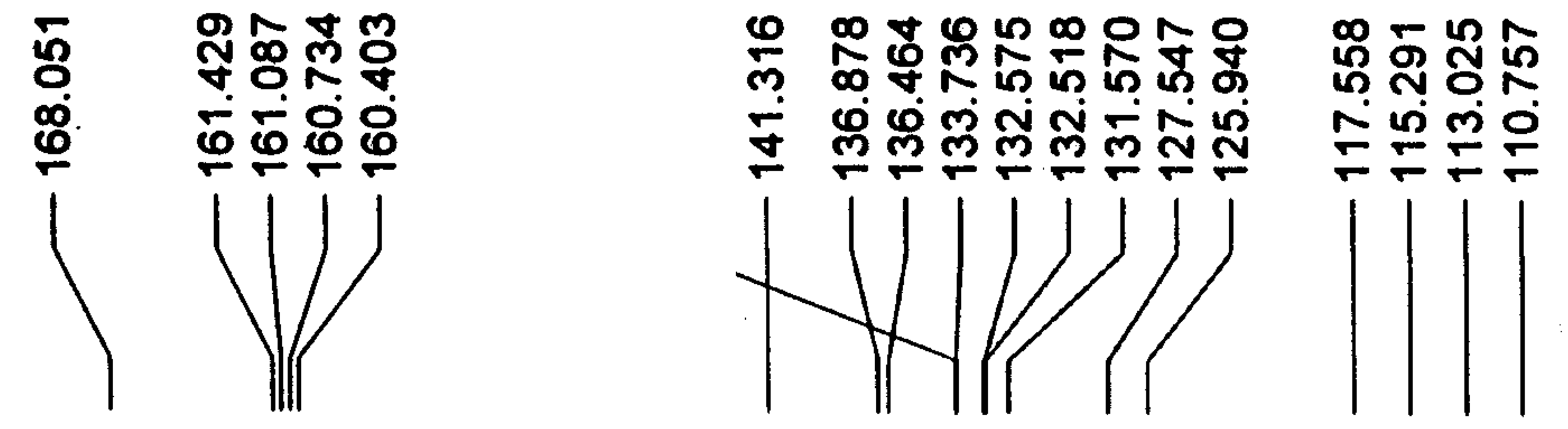

\section{8c (dication) 13C CDCI3-TFA}






||||

\section{$\mathrm{Ni}-8 \mathrm{C}$}




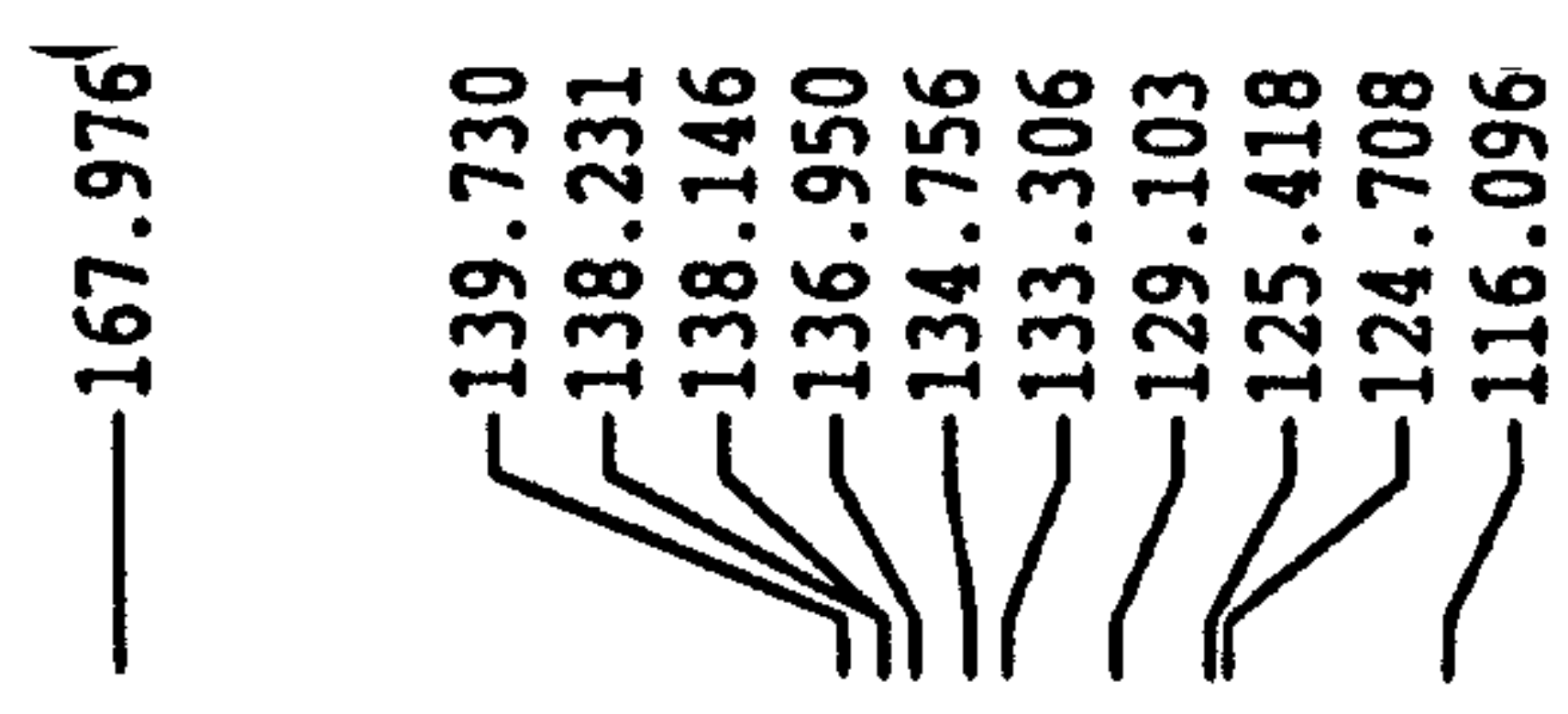

W

\section{$\mathrm{Ni}-8 \mathrm{c} \quad 13 \mathrm{C}$}

Qurrent Dato Parameters

WNE OFBCNI

ExpNo

13

M2 - Acquisittion Parameters

Date.

Time $\quad 21.35$

PROBHD $5 \mathrm{~mm} \mathrm{BBO} \mathrm{BD-1H}$

PULPROS $29 \mathrm{gg} 30$

TD $\quad 65516$

solvar $\quad \mathrm{COCl} 3$

NS

DS

$\quad 17985.611 \mathrm{~Hz}$

PIDRES $\quad 0.274439 \mathrm{~Hz}$

$\begin{array}{cc}A 0 & 1.8219508 \\ 10 & 14596.5\end{array}$

Do $\quad 27.800$ usec

DB 20.00 usec

$300.0 \mathrm{~K}$

DI $\quad 2.00000000 \mathrm{sec}$

dil $\quad 0.03000000 \mathrm{sec}$

$d 12 \quad 0.00002000$ sec

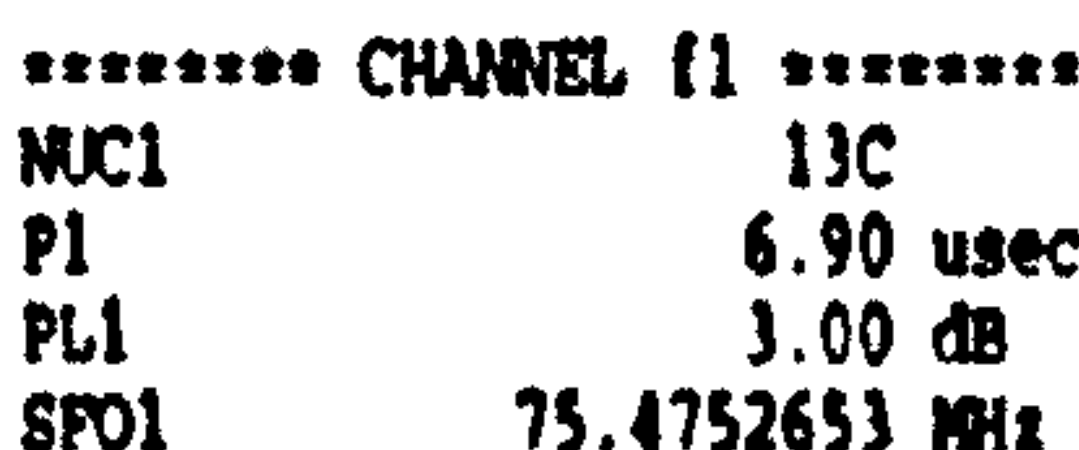

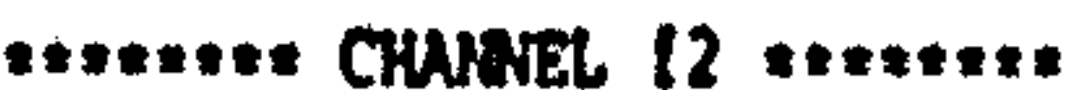
CPDPRO2

MUC2 IH

PCPD2 $\quad 103.00$ usec

Pes

PLi2

St13

$3.00 \mathrm{~dB}$

$26.00 \mathrm{de}$

300.1312005 HH2

Z - Processing poraneters

S1 32768

SF $\quad 75.1677190$ พнะ

NON

SSB

18
GB

D.1

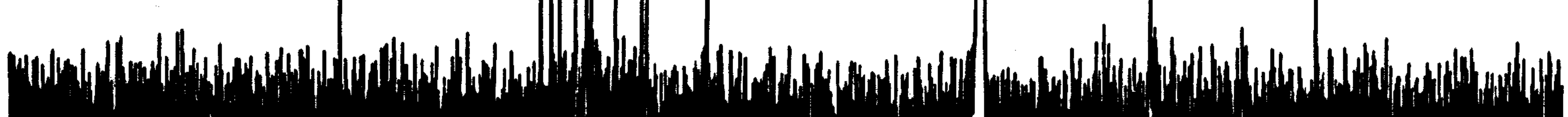

10 Rar plot parameters

CX $20.00 \mathrm{~cm}$

cr $\quad 12.50 \mathrm{~cm}$

$215.000 \mathrm{ppm}$
$11 \mathrm{FP}$

$\begin{array}{lr}71 & 16225.56 \mathrm{~Hz} \\ 72 & .5 .000 \mathrm{pom}\end{array}$

$72 \quad-377.34 \mathrm{~Hz}$

$\begin{array}{lr}\text { PPHCX } & 11.00000 \mathrm{ppm} / \mathrm{cm} \\ \text { HzOA } & 830.14490 \mathrm{~Hz} / \mathrm{cm}\end{array}$

ppm 200

175

150

125

100

75.

50

25 
Ni-8d

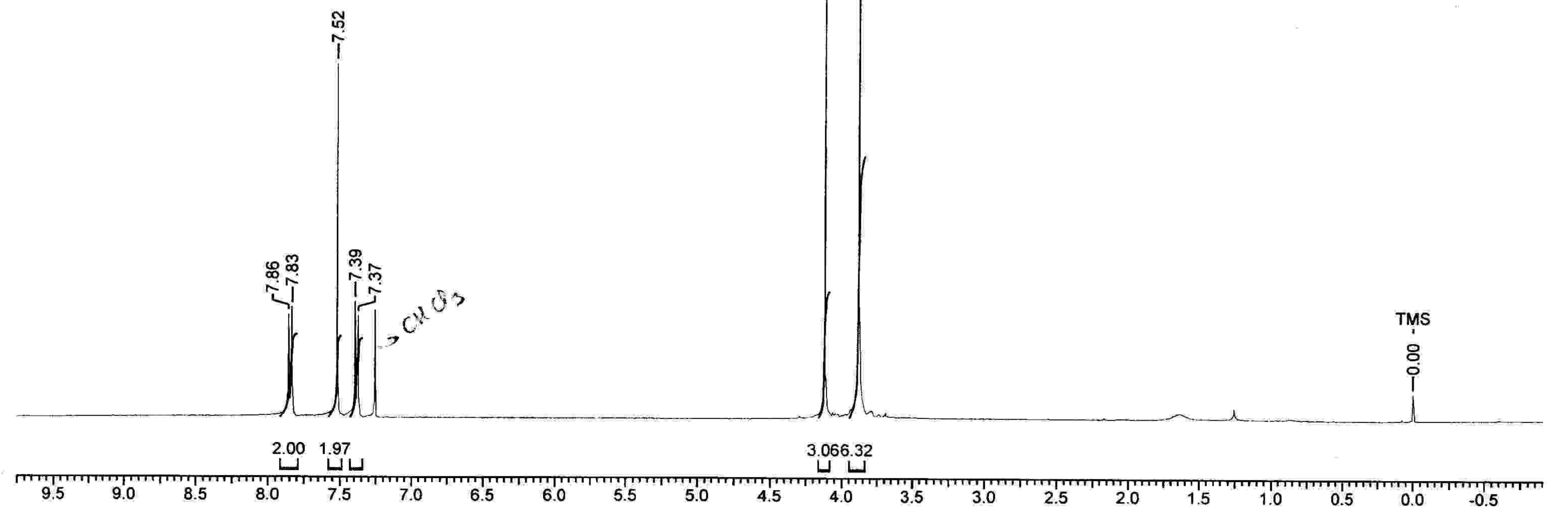




\section{$\mathrm{Ni}-8 \mathrm{~d} \quad 13 \mathrm{C}$}






\section{0b (free base)}

$\mathrm{T}=255 \mathrm{~K}$
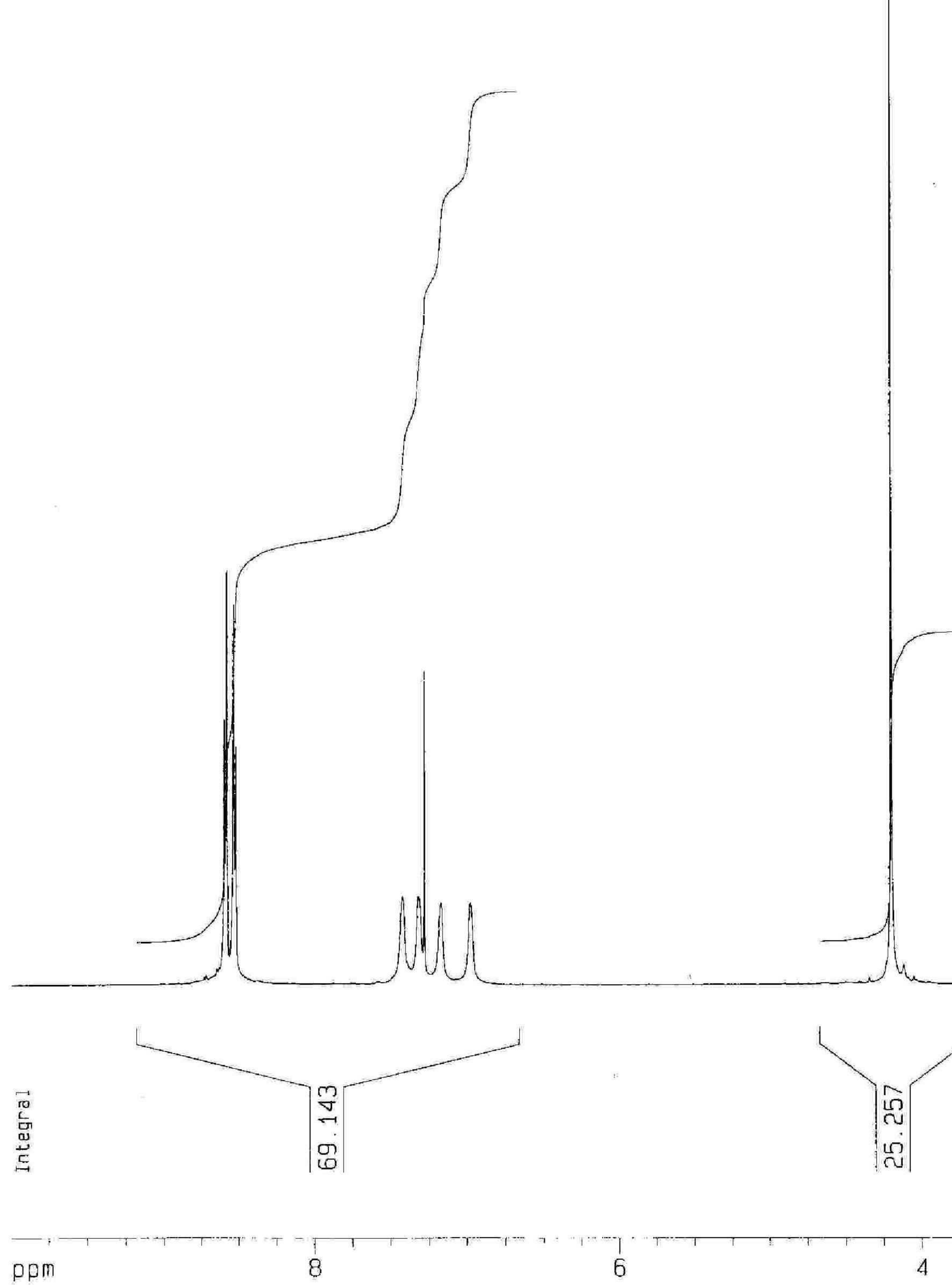

Current Data Parameters

NAME

EXPNO

PROCNO

F2 - Acquisition Parameters

Date 20020225

$\begin{array}{lr}\text { Date.- } & 20020255 \\ \text { Time } & 14.19\end{array}$

INSTRUMM spect

PROBHD $5 \mathrm{~mm}$ TXI $13 \mathrm{C}$

PULPROG

2gpr

TO

SOLVENT

NS

DS

$5 W H$

FIDRES

$A Q$
$R G$

DW

$D E$

TE

01

d12

d13

\section{$==$}

NUC1

P1

PL1

PL9

SF01

F2 - Processing parameters

$\begin{array}{cc}\text { SI } & 32768 \\ \text { SF } & 500.1276276 \mathrm{MHz}\end{array}$

WDW

SSB

LB

GB

$\mathrm{PC}$ $0.305176 \mathrm{~Hz}$

1.6384500 sec 287.4

50.000 usec 6.00 usec

3.000000

$0.00002000 \mathrm{sec}$

$0.00000300 \mathrm{sec}$

CHANNEL $f \exists===$$$
14
$$

11.90 usec

$0.00 \mathrm{~dB}$

$120.00 \mathrm{~dB}$

$500.1287499 \mathrm{MHZ}$

0

$0.00 \mathrm{~Hz}$

0

1.00

10 NMR plot parameters

CX

F IP

$F_{1}$

F $2 P$

$F 2$

PPMCM

HZCM

$$
\begin{gathered}
22.00 \mathrm{~cm} \\
9.998 \mathrm{ppm} \\
5000.4 \mathrm{~B} \mathrm{~Hz} \\
-2.296 \mathrm{ppm} \\
-1148.39 \mathrm{~Hz} \\
0.55885 \mathrm{ppm} / \\
279.49399 \mathrm{~Hz} / \mathrm{c}
\end{gathered}
$$




\section{0b $13 c$}




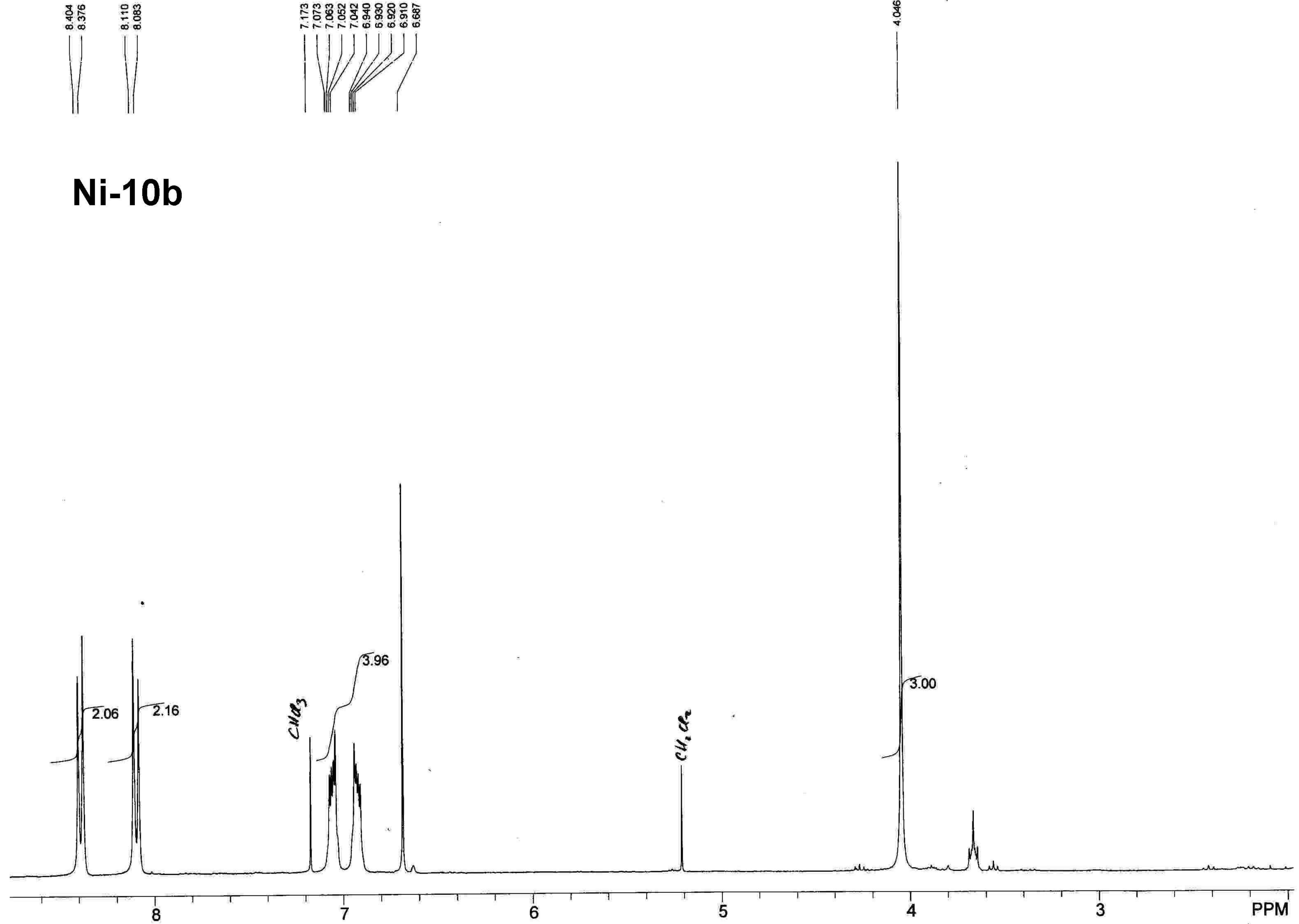




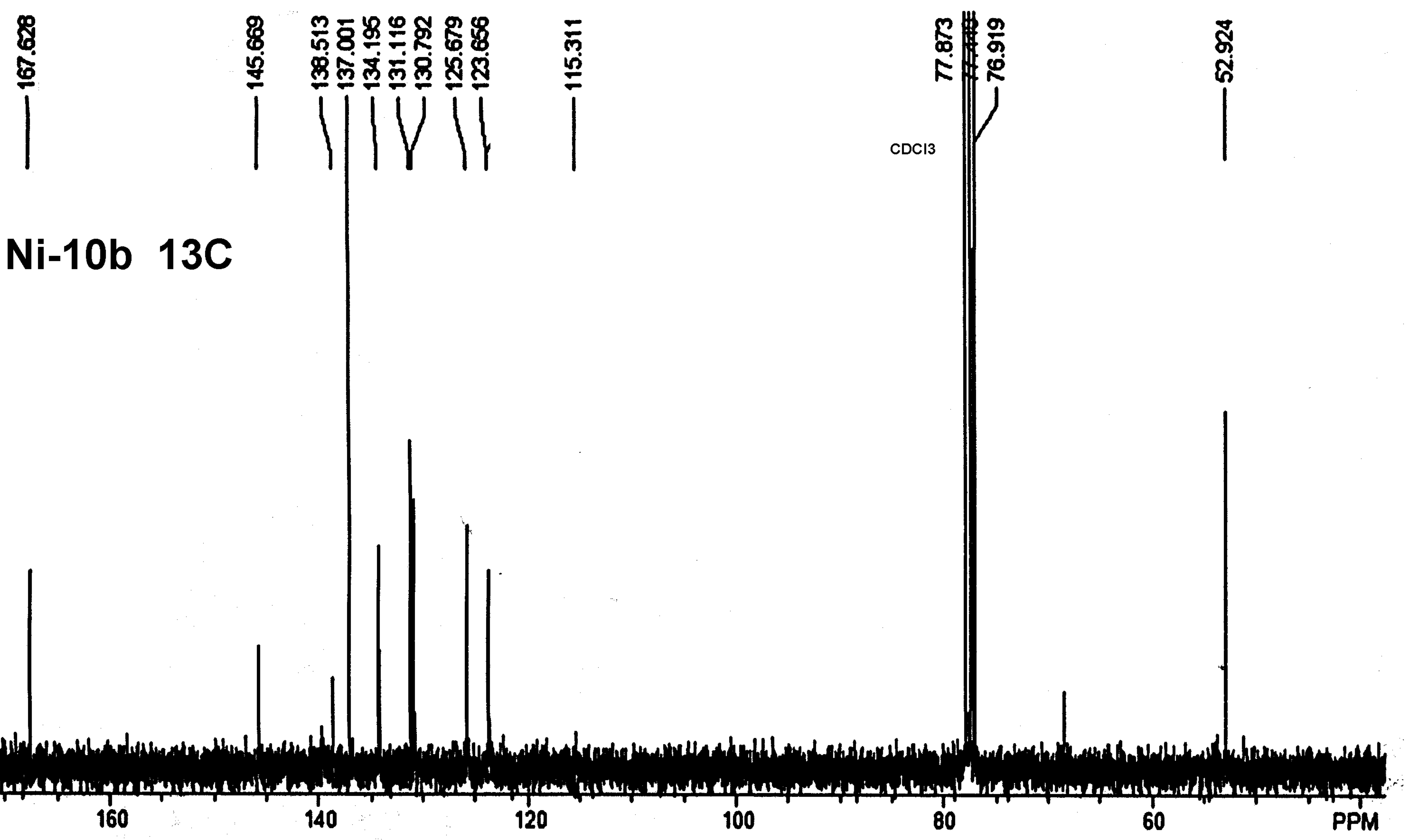



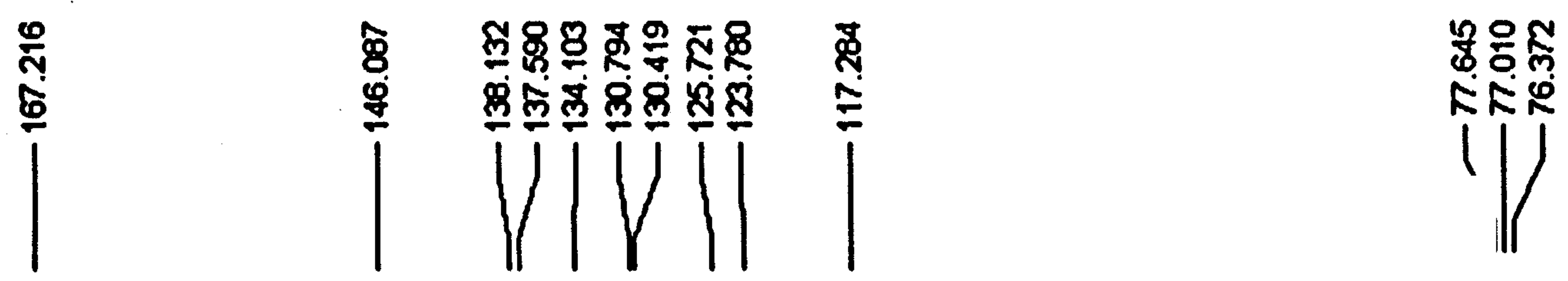

\section{Pd-10b CDCl3}

